\title{
THE AMERICAN BAR ASSOCIATION SUGGESTS AN ANSWER TO THE "FAIR TRIAL-FREE PRESS" DILEMMA
}

In response to the increasing controversy subsumed under the label of "fair trial-free press," the American Bar Association has issued a Tentative Draft of Standards. This comment examines the impediments posed to a constitutionally fair trial by unbridled publicity and evaluates the proposed solutions, with particular emphasis upon the $A B A$ 's recommendations.

$\mathrm{T}$ HE RIGHTS of the criminally accused have received ever increasing protection in recent years. ${ }^{1}$ At the same time, however, it has become apparent that inflammatory publicity and other prejudicial extraneous influences may impair the right to a fair trial. ${ }^{2}$ Indeed, several recent Supreme Court cases have dealt with the prejudicial effect of publicity on the fairness of state criminal prosecutions. ${ }^{3}$ It is here contended that the problem of ensuring fairness and impartiality involves more than a consideration of the impact of prejudicial publicity upon the impartiality of the trier of fact. Thus, the term "prejudicial extraneous influence" has been selected to denote any influence which tends to result in the conviction of the accused other than competent and permissible presentation at trial.4 This comment will focus first upon the rights of the accused which may be diluted by the impingement of prejudicial extraneous influences. Thereafter, suggested methods of control will be evaluated, giving primary consideration to the remedies proposed in the Tentative Draft of Standards of the American Bar Association's Advisory Committee on Fair Trial and Free Press. ${ }^{5}$

${ }^{1}$ See, e.g., Miranda v. Arizona, 384 U.S. 436 (1966); Griffin v. California, 380 U.S. 609 (1965); Pointer v. Texas, 380 U.S. 400 (1965); Escobedo v. Illinois, 378 U.S. 478 (1964); Malloy v. Hogan, 378 U.S. 1 (1964); Mapp v. Ohio, 367 U.S. 643 (1961). See generally Brennan, Extension of the Bill of Rights to the States, 44 J. URBan LAw 11 (1966); Weihofen, Supreme Court Review of State Criminal Procedure, 10. AM. J. LEGAL HIST. 189 (1966).

2 See, e.g., Inbau \& Sowle, Cases on Criminal Justice 1089-91 (2d ed. 1964); Goldfarb, Public Information, Criminal Trials and the Cause Celebre, 36 N.Y.U.L. Rev. 810-12 (1961); Jaffee, The Press and the Oppressed-Part I, 56 J. CrIM. L., C. \& P.S. 1 (1965); Will, Free Press vs. Fair Trial, 12 DEPaUl L. REv. 197-201 (1969); Nate, 54 KY. L.J. 141, 143-50 (1965).

Sheppard v. Maxwell, 384 U.S. 333 (1966); Rideau v. Louisiana, 373 U.S. 723 (1963); Beck v. Washington, 369 U.S. 541 (1962); Irvin v. Dowd, 366 U.S. 717 (1961).

- See, e.g., notes 60-61 infra and accompanying text.

- aba Advisory Committee on fair Trial and Free Press, Standards Relating to Fair Trial and Free Press (Tent. Draft Dec. 1966). 


\section{Right to a Fair Trial}

The accused's right to a fair trial has long been fundamental to Anglo-American criminal justice. ${ }^{b}$ The sixth amendment to the Constitution guarantees the defendant in a federal criminal trial the right to a trial by an impartial jury. ${ }^{7}$ Although this sixtl amendment right has not been extended to state criminal proceedings as an element of fourteenth amendment due process, ${ }^{8}$ due process does require that the accused receive a fair trial ${ }^{9}$ which includes the requirement that the decision of the trier of fact-whether judge or jury-must be impartially rendered. ${ }^{10}$

\section{AN IMPARTIAL JURY AT IMPANELMENT}

In one of its earliest forms the jury consisted of a group of witnesses to the alleged offense. ${ }^{11}$ However, by Lord Coke's day a juror was required "to be indifferent as he stands unsworne."12 This standard was carried to the colonies, and under early American law a prospective juror was disqualified if he had formulated an opinion

- See Coke, LITtzeton $\$ \S 155-56$ (b). A fair trial, however, does not mean a trial free from all error. E.g., State v. Haffa, 246 Iowa 1275, 1286, 71 N.W.2d 35, 42 (1955); State v. Rush, 108 W. Va. 254, 260, 150 S.E. 740, 742 (1929).

7 U.S. Const. amend. VI. The impartiality of a decision is also of interest to the government, for such a quality is necessary for fulfillment of its mandate to fairly administer criminal justice. Further, controls of prejudicial publication during criminal proceedings would relieve the government of the financial and manpower expenditure aecompanying relitigation of cases in which press coverage has caused reversal of a prior conviction. See Palko v. Connecticut, 302 U.S. 319, 328 (1937); State v. Van Duyne, 43 N.J. 369, 389, 204 A.2d 841, 852 (1964), cert. denied, 380 U.S. 987 (1965); Comment, 57 Nw. U.L. REv. 217, 225-26 (1962).

${ }^{8}$ See Fay v. New York, 332 U.S. 261 (1947); Palko v. Connecticut, supra note 7, at 324 (dictum); Maxwell v. Dow, 176 U.S. 581 (1899). However, all state constitutions have some provision for the right of trial by jury in criminal cases. See Irvin v. Dowd, 366 U.S. 717, 721-22 (1961), citing Columbia UniverstTy Legislative Drafting Research Fund, Index Digest of State Constitutrons 578-79 (1959).

- "A fair trial in a fair tribunal is a basic requirement of due process." In re Murchison, 349 U.S. 133, 136 (1955); accord, In re Oliver, 333 U.S. 257 (1948). See generally Goldfarb, supra note 2 , at $815-18$.

${ }^{10}$ In re Murchison, supra note 9; Tumey v. Ohio, 273 U.S. 510 (1927) (trial before a judicial officer who had a financial interest in conviction held a denial of due process). See generally Comment, 51 CoRNel. L.Q. 306, 306.08 (1966); Comment, 57 Nw. U.L. REv. 217, 218-20 (1962); 44 CALIF. L. REv. 425 (1956).

${ }^{12}$ See Estes v. Texas, 381 U.S. 532, 557-59 (1965) (Warren, C.J., concurring); Singer v. United States, 380 U.S. 24, 27-34 (1965). See generally 1 HOLDSWORTH, A HIsTORY OF THE ENGLish LAW 298-350 (3d ed. 1922); RAdiN, ANglo-AMERIGaN Legal History 204-08 (1936); Warner, The Development of Trial by Jury, 26 TENN. L. REv. 459 (1959); White, Origin and Development of Trial by Jury, 29 TENN. L. REv. 8 (1961).

32 COKE, LITTLETON $\$ 155$ (b). 
as to the guilt or innocence of the accused. ${ }^{13}$ With the increase of literacy and the development of mass communication this standard was abandoned, since it was believed that in newsworthy cases it would be difficult to impanel literate jurors who had not formed some opinion of the case. ${ }^{14}$ The current standard, adopted in 1878 by the Supreme Court in Reynolds $v$. United States, ${ }^{15}$ is that a venireman need not be dismissed for cause even though be admits to having an opinion as to the guilt of the accused if he can state to the court's satisfaction that he will lay aside this opinion and render a fair and impartial decision based solely on the evidence as presented at trial. ${ }^{16}$ The trial judge's discretionary finding on the challenge of such a juror will be set aside on appeal only upon a showing of manifest error. ${ }^{17}$ Under the Reynolds standard a defendant who claims that his trial was unfair because of the intrusion of prejudicial extraneous influences must bear the burden of proving "actual" rather than "probable" prejudice. ${ }^{18}$

${ }^{18}$ People v. Miller, 125 Cal. 44, 57 Pac. 770 (1899); Greenfield v. People, 74 N.Y. 277 (1878) (pex curiam); People v. Allen, 43 N.Y. 28, 34 (1870). But see United States v. Burr, 25 Fed. Cas. 49, 51 (No. 14692g.) (C.C.D. Va. 1807) (opinion by Marshall, C.J.).

IA See Reynolds v. United States, 98 U.S. 145, 155-56 (1878); Comment, 38 So. CAt.

L. REv. 672, 673-76 (1965).

1598 U.S. 145 (1878).

${ }^{10}$ The underlying rationale of the Reynolds approach has been explicated in the following terms:

"When, shortly before and during a trial, public news media irresponsibly publish incompetent and prejudicial information, the difficulty of maintenance of fairness in the administration of justice is manifest. That the work of the courts may continue without making jury service unduly burdensome, we are allowed to indulge an assumption that the individual jurors will observe the court's admonition and will not read. articles or listen to reports about the subject of the trial." Holmes v. United States, 284 F.2d 716, 718 (4th Cir. 1960). (Emphasis added.)

${ }^{27}$ E.g., Holt v. United States, 218 U.S. 245, 248 (1910); Spies v. Illinois, 123 U.S. 131 (1887); Hopt v. Utah, 120 U.S. 430 (1887).

${ }_{18}$ See United States ex rel. Darcy v. Handy, 351 U.S. 454, 462 (1956); Stroble v. California, 349 U.S. 181, 198 (1952); Ferrari v. United States, 244 F.2d 132, 138-39 (9th Cir.), cert. denied, 355 U.S. 873 (1957); Smith v. United States, 236 F.2d 260, 26970 (8th Cir.), cert. denied, 352. U.S. 909 (1956); United States v. Carruthers, 152 F.2d 512, 519 (7th Cir. 1945), cert. denied, 327 U.S. 787 (1946); Oxenberg v. State, 362 P.2d 893, 899 (Alaska), cert. denied, 368 U.S. 56 (1961); Morgan v. State, 211 Ga. 172, 84 S.E.2d 365 (1954). But see Sheppard v. Maxwell, 384 U.S. 333 (1966); Estes v. Texas, 381 U.S. 532 (1965); Rideau v. Louisiana, 373 U.S. 723 (1963); Jaffee, Trial by Newspaper, 40 N.Y.U.L. REv. 504, 513-17 (1965); Comment, 51 CoRNELL L.Q. 306, 308-13 (1966); Comment, 33 U. CHI. L. REv. 512, 516 (1966).

The distinction between "actual" and "probable" prejudice is not altogether clear. Because jurors are not allowed to impeach their verdicts, see notes 175-77 infra and accompanying text, an accused can probably never demonstrate a concrete, causal link between prejudicial pubhicity and an adverse verdict unless a juror makes the im- 
More than eighty years after Reynolds, in Irvin $v$. Dowd, ${ }^{10}$ a defendant, for the first time exhibited to the Supreme Court's satisfaction actual prejudice at jury impanelment. No accused had successfully asserted jury bias in the interim for two reasons: first, the Supreme Court had never stated what facts were necessary to establish the trial judge's "manifest error" in accepting a juror's avowal of impartiality;"20 and, second, the issue had been avoided by finding that the defendant had waived his opportunity to object to pre-trial publicity by failing to exhaust his procedural safeguards. 21 In Irvin, however, the Coùrt stated that when intense community hostility toward the accused is manifest in the record of the voir dire examination, a "finding of impartiality does not meet constitutional standards." 22 Despite the reversal, Irvin did not purport to alter the Reynolds test in any way. ${ }^{23}$

The standard for juror impartiality was rendered more uncertain by Beck $v$. Washington, ${ }^{24}$ in which Irvin was distinguished on its facts $^{25}$ and the claim of a denial of a fair trial based on

probable declaration, on voir dire or during trial, that he will not decide guilt or innocence solcly upon the evidence presented at trial. The cases employing the term "actual prejudice" have not required such a link, and to the extent the phrase suggests such a connection, it is misleading.

On the other hand, the "probable prejudice" standard requires more than a demonstration of the existence of prejudicial publicity. To win reversal under this test, an accused must link the publicity with actual or potential jurors just as he must under the "actual prejudice" standard. The distinction between "actual" and "probable" prejudice may lie not in the quantum of proof required for reversal but rather in the orientation of the appellate court.

"Actual" and "probable" prejudice may merely be labels for an unannounced weighing of the interaction between the nature and extent of the publicity, the number of actual or potential jurors aware of the prejudicial information, and the extent to which the accused availed himself of the procedural safeguards. If this is the distinction, the Reynolds-Irvin "test" for prejudice may not be capable of g'eneral application and instead proceeds on a case-by-case basis, with an emphasis sin numbers that seems to obscure the basic issue of fairness. See note 27 infra.

${ }^{10} 366$ U.S. 717 (1961); see Manes, Irvin v. Dowd: Retreat from Reality, 22 LAW IN Transition 46 (1962); Comment, 51 Cornelr L.Q. 306, 310 (1966).

${ }^{20}$ See Comment, 38 Sr. JohN's L. Rev. 136, 144-45 (1963).

${ }^{21}$ See notes 111-17 infra and accompanying text.

${ }^{22}$ Irvin v. Dowd, 366 U.S. 717, 728 (1961). An examination of the voir dire transscript revealed that ninety per cent of the veniremen had to be excused for cause and that eight of the twelve jurors initially thought that the defendant was guilty but vowed they would be impartial. Id. at 727. "One [juror] said that he "could not . . . give the defendant the benefit of the doubt that he was innocent.' "Id. at 728.

${ }^{28}$ Id. at 723-24; Comment, 51 CoRNell L.Q. 306, 308-09 (1966). See note 18 supra.

24369 U.S. 541 (1962).

${ }^{25}$ The Supreme Court pointed to the following reasons for affirming the conviction in Beck: (1) The publicity was factual and not inflammatory. (2) Only twenty-seven per cent of the prospective jurors examined on voir dire had formed an opinion of 
prejudicial pre-trial publicity was rejected. ${ }^{26}$ Thus, the constitutional standard for an impartial jury at impanelment is not at present clearly defined; ${ }^{27}$ however, it is suggested that if fairness is to be the governing consideration, no juror who admits to having formed an opinion that the accused is guilty should be impaneled.

\section{SELF-INCRIMINATION}

The freedom from compulsory self-incrimination is now a constitutional right of the criminally accused in state as well as federal prosecutions. ${ }^{28}$ Thus, a conviction may not stand where an accused's

the accused's guilt. (3) None of the jurors had expressed an opinion of the accused's guilt formed prior to the trial. (4) The publicity and the trial were separated by a significant period of time. (5) The accused did not challenge for cause any juror finally selected. The court relied on the fifth distinction to indicate that the accused was satisfied that the jurors were unbiased. Id. at 556-58. See Comment, 51 CoRNELI L.Q. 306, 309.10 (1966).

26369 U.S. at $557-58$.

${ }^{27}$ Compare Geagan v. Gavin, 292 F.2d 244 (lst Cir. 1961), cert. denied, 370 U.S. 903 (1962), with United States ex rel. Bloeth v. Denno, 313 F.2d 364 (2d Cir.), cert. denied, 373 U.S. 978 (1963).

\begin{tabular}{|c|c|c|}
\hline $\begin{array}{l}\text { without inquiry as to opinion } \\
\text { Jurors having an opinion }\end{array}$ & $43.8 \%$ & $25.4 \%$, \\
\hline (\% of total venire) & $40.6 \%$ & $54.7 \%$ \\
\hline $\begin{array}{l}\text { Jurors having no opinion } \\
\text { (\% of total venire) }\end{array}$ & $15.6 \%$ & $19.9 \%$ \\
\hline $\begin{array}{l}\text { Jurors having opinion } \\
\text { (\% of those questioned as } \\
\text { to opinion) } \\
\text { Turors having opinion }\end{array}$ & $68.3 \%$ & $72.2 \%$ \\
\hline (\% of defendant's jury) & $16.6 \%$ & $50.0 \%$ (8 of 16$)$ \\
\hline
\end{tabular}

In both cases, the jurors who admitted preconceived inclinations of guilt or innocence "expressed themselves in various terms as being able to change the opinion or render an impartial verdict." 313 F.2d at 368-69.

The Geagan court affirmed a conviction where, of 965 prospective jurors questioned on their opinions of the defendant's guilt, more than sixty-eight per cent including two persons who actually served on the jury, admitted preconceived inclinatious as to his culpability. Whether these opinions would have supported acquittal or conviction was not ascertained. 292 F.2d at 247. In Denno, on the other hand, reversal was granted where thirty-one of thirty-nine veniremen questioned confessed having preconceptions, and fifty per cent of the jurors seated thought initially that the accused was guilty.

\begin{tabular}{|c|c|c|c|c|}
\hline & $\begin{array}{l}\text { Total } \\
\text { Venire }\end{array}$ & $\begin{array}{l}\text { Excused for health } \\
\text { or hardship or other } \\
\text { ground without opinion }\end{array}$ & Opinion & No Opinion \\
\hline $\begin{array}{l}\text { Geagan } \\
\text { Denno }\end{array}$ & $\begin{array}{r}1204 \\
96\end{array}$ & $\begin{array}{r}239(25.42 \%) \\
42(43.75 \%)\end{array}$ & $\begin{array}{l}659(54.73 \%) \\
39(40.62 \%)\end{array}$ & $\begin{aligned} 306 & (19.85 \%) \\
15 & (15.68 \%)\end{aligned}$ \\
\hline
\end{tabular}

${ }^{28}$ Malloy v. Hogan, 378 U.S. 1 (1964). 
coerced confession has been admitted into evidence, ${ }^{29}$ notwithstanding the admission of independent evidence sufficient to establish his guilt. ${ }^{30}$ Moreover, a confession given voluntarily will not be admissible unless the accused is afforded certain procedural safeguards at the time of his incriminating disclosures. ${ }^{31}$ Lest the jury be led to infer guilt from the accused's silence at trial, neither the court nor the prosecution is permitted to comment on his failure to testify in his own behalf. ${ }^{32}$

In view of the safeguards with which the freedom from selfincrimination is circumscribed, it would seem anomalous to permit the injection of incriminating statements into the proceeding by extraneous sources when such statements may ultimately be excluded or never offered as evidence. Even if a confession were later admitted into evidence, the fairness and impartiality of the proceeding might be vitiated by the manner or timing of the extrajudicial disclosure. In Rideau v. Louisiana, ${ }^{33}$ for example, the Supreme Court reversed a conviction for failure to grant a change of venue where two months prior to the trial a sound film showing the accused confessing in an "interview" with the sheriff was televised by a local station on three occasions. ${ }^{34}$ The Court did not scrutinize the transcript of the voir dire examination as it had done in Irvin..$^{35}$

\footnotetext{
s9 E.g., Haynes v. Washington, 373 U.S. 503, 510 (1963) (length and illegality of detention under state law); Lynumn v. Illinois, 372 U.S. 528 (1963) (capitalizing on individual weakness or incapacities); Reck v. Pate, 367 U.S. 433 (1961) (physical deprivations such as lack of sleep or food); Payne v. Arkansas, 356 U.S. 560 (1958) (threats of imminent danger); Chambers v. Florida, 309 U.S. 227 (1940) (repeated or extended interrogation); Brown v. Mississippi, 297 U.S. 278 (1936) (physical beatings).

20 Blackburn v. Alabama, 361 U.S. 199 (1960); Spano v. New York, 360 U.S. 315 (1959); Payne v. Arkansas, 356 U.S. 560 (1958).

21 State courts must exclude incriminating pre-indictment statements made by a defendant during a time when his right to counsel was being violated. Escobedo v. Illinois, 378 U.S. 478 (1964). In addition, the Court has laid down procedures which must be adhered to before any confession will be admissible Miranda v. Arizona, 384 U.S. 436, 471-79 (1966).

2s See O'Connor v. Ohio, 385 U.S. 92 (1966) (per curiam); Griffin v. California, 380 U.S. 609 (1965).

373 U.S. 723 (1963).

"Id. at 724 .

${ }^{8 s}$ "[W] do not hesitate to hold, without pausing to examine a particularized transcript of the voir dire examination of the members of the jury, that due process of law in this case required a trial before a jury [from another] . . community ...." Id. at 727. It was this use of speculative prejudice that caused Mr. Justice Clark to reject the majority's approach: "I must part company with the Court, however, not so much because it deviates from the principles established in Irvin but because it applies no principles at all. It simply stops at this point, without establishing any
} 
The extraneous influence was apparently considered to be so prejudicial that no showing of actual prejudice was required to establish the unfairness of the trial which followed..$^{36}$

To be contrasted with Rideau is the Court's decision in Stroble v. California ${ }^{37}$ which affirmed a conviction despite the publication of the accused's incriminating statement to the prosecutor in lurid detail six weeks prior to the trial. ${ }^{38}$ There was no proof "that any juror was in fact prejudiced by the newspaper stories," 39 nor was there an "affirmative showing that any community prejudice ever existed or in any way affected the deliberation of the jury." ${ }^{40}$ However, during the period between the accused's arrest and his trial the mass media devoted extensive coverage to "crimes against children and defendant's crime in particular." 41 Perhaps Stroble and Rideau may be reconciled on the basis that the former involved community outrage at a particular type of crime, whereas the latter involved community hostility directed toward the accused..$^{42}$ Nevertheless, basic fairness would seem to require that the accused's freedom from self-incrimination be protected by permitting only those incriminating statements which are admitted at trial to influence the jury from the point in time at which such statements are admitted.

\section{Evidentiary Safeguards}

An accused can only be convicted on the basis of evidence obtained without violation of his constitutional rights ${ }^{43}$ and presented against him in court. ${ }^{44}$ Moreover, certain rules of evidence have

substantial nexus between the televised 'interview' and petitioner's trial, which occurred almost two months later." Id. at 729. See note 18 supra.

s6 "For anyone who has ever watched television the conclusion cannot be avoided that this . . . was Rideau's trial-at which he pleaded guilty to murder." 373 U.S. at 726. (Emphasis in original.)

${ }^{87} 343$ U.S. 181 (1952).

ss The defendant's statement contained admissions of sex play with his victim, a six-year-old girl, and other children on occasions prior to the killing. Id. at 199 (dissenting opinion). In addition, the local newspapers referred to the accused as a "werewolf," a "fiend," and a "sex-mad killer." Id. at 192.

${ }^{\text {so }}$ Id. at 194-95.

10 Id. at 195 . .

¿ People v. Stroble, 36 Cal. 2d 615, 620, 226 P.2d 330, 334 (1951), affd, 343 U.S. 181 (1952).

\&2 Cf. United States v. Maybury, 274 F.2d 899, 902-03 (2d Cir. 1960).

43 Mapp v. Ohio, 367 U.S. 643, 654-60 (1961). See Schmerber v. California, 384 U.S. 757, 766-72 (1966) (compelled blood test evidence is constitutionally admissible), 1967 DuRE L.J. 366.

"See note 66 infra. 
evolved which preclude the introduction of matter which it is believed will lead to other than a reliable determination of guilt. ${ }^{45}$ Such rules govern the admissibility of hearsay, ${ }^{46}$ opinions, ${ }^{47}$ and tests, ${ }^{48}$ all of which are admissible only under certain circumstances and then only for specified purposes. ${ }^{49}$ For example, evidence of the accused's bad character, generally shown by a prior criminal record, is admissible as part of the prosecution's initial case only for limited purposes. ${ }^{50}$ Evidence of bad character is not irrelevant, but the danger of prejudice to the accused outweighs its probative value. 51 The effectiveness of these exclusionary rules may be greatly impaired, however, if the evidence which they seek to exclude is permitted to influence the jury through communication from extraneous sources.52 In Marshall $v$. United States ${ }^{53}$ the Supreme Court, in the exercise of its supervisory power over the federal courts, ${ }^{54}$ reversed a conviction where during the trial jurors had read newspaper accounts of the defendant's prior criminal record. The trial judge had refused an offer by the prosecution of proof of prior misdeeds, ruling that the evidence was immaterial and prejudicial to the defendant. .55 Noting that the jurors had been exposed to "information of a character which the trial judge ruled was so prejudicial it could not be directly offered as evidence,"50 the Court stated that the prejudice to the defendant was perhaps greater than if the

\footnotetext{
48 Wigmore, Evidence 5 (student ed. 1985).

¿8 UNIFORM RULE OF Evidence 63. See generally MCCORMick, Evidence $\$ \$ 223-29$ (1954).

"2 See generally id. $\$ \S 11-14$.

${ }^{48}$ See id. $\$ 174$ and authorities cited therein; Orfield, Relevancy in Federal Criminal Evidence, 49 NEB. L. REv. 485, 553-59 (1964) and authorities cited therein.

“9 See generally MCCoRMick, Evidence $\$ \S 11-14,174,223-29$ (1954) and authorities cited therein.

${ }^{\text {so }}$ See id. $\$ 157$ and authorities cited therein; Orfield, supra note 48 , at $517 \cdot 31$ and authorities cited therein. But see Spencer v. Texas, 385 U.S. 554 (1967).

62 MCCORMICK, EVIDENCE $\$ 157$ (1954).

62 "The exclusion of such evidence in court is rendered meaningless when news media make it available to the public." Sheppard v. Maxwell, 384 U.S. 338, 360 (1966). The Court went on to mentain specifically the publication of Sheppard's refusal to submit to a lie detector test, statements by witnesses who never appeared at the trial, and detailed descriptions of clues found by the police but never introduced as evidence in the trial. Id. at $\mathbf{3 6 0 - 6 1}$.

ss 360 U.S. 310 (1954) (per curiam).

“4 See Mallory v. United States, 354 U.S. 449 (1957); McNabb v. United States, 318 U.s. 332,341 (1943).

ss 360 U.S. at $311 \cdot 12$.

${ }^{5}$ Id. at 312 .
} 
evidence had reached the jury as part of the prosecution's case, ${ }^{57}$ for the exposure through news accounts was not "tempered by protective procedures."58 This result was reached despite the trial judge's denial of a motion for mistrial based upon the jurors' assurances that, even though they had read the accounts, they could decide the case solely on the basis of the evidence in the record and that they felt no prejudice against the accused as a result of having read the accounts. ${ }^{59}$

In interpreting Marshall, the courts of appeals have reversed convictions where some members of the jury had been exposed during the proceeding to information concerning the accused's prior criminal record either by disclosure of inadmissible evidence ${ }^{60}$ or by newspaper articles. ${ }^{61}$ In these cases the defendant had only to show a significant exposure to the prejudicial extraneous influence, ${ }^{62}$ rather than the actual prejudice required under Irvin, ${ }^{63}$ to establish lack of impartiality at impanelment in state prosecutions. Avowals of impartiality and lack of prejudice by jurors exposed to such influences during trial are not deemed curative under $M$ arshall, ${ }^{64}$ but at least one federal court has taken the position that avowals of im-

67 Id. at 813 .

${ }^{68}$ Ibid.

${ }^{50}$ Id. at 312. The Court has reconsidered Marshall only once. In Janko v. United States, 366 U.S. 716 (1961), the Court reversed the conviction summarily. The opinion stated that the reversal was the result of error confessed by the Solicitor General and of an examination of the entire record. However, Mr. Justice Frankfurter, concurring in Irvin v. Dowd, 366 U.S. 717 (1961), decided one week after Janko, stated that the reversal was due to prejudicial newspaper publicity which had "poisoned the outcome." Id. at 730.

${ }^{\circ 0}$ Osborne v. United States, 351 F.2d 111 (8th Cir. 1965); Maestos v. United States, 341 F.2d 493 (10th Cir. 1965); Lane v. Maryland, 320 F.2d 179 (4th Cir.), cert. denied, 368993 (1963); Thurman v. United States, 316 F.2d 205 (9th Cir. 1963); Paschal v. United States, 306 F.2d 398 (5th Cir. 1962); United States v. Rinaldi, 301 F.2d 576 (2d Cir. 1962); United States v. Jacangelo, 281 F.2d 574 (3d Cir. 1960). But see Bacino v. United States, 316 F.2d 11 (10th Cir. 1963).

61 United States v. Kum Seng Seo, 300 F.2d 623 (3d Cir. 1962); United States v. Accardo, 298 F.2d 133 (7th Cir. 1962); Holmes v. United States, 284 F.2d 716 (4th Cir. 1960); Coppedge v. United States, 272 F.2d 504 (D.C. Cir. 1959), cert. denied, 368 U.S. 855 (1961). But see Marshall v. United States, 355 F.2d 999 (9th Cir.), cert. denied, 385 U.S. 815 (1966); United States v. Kahaner, 317 F.2d 459 (2d Cir.), cert. denied, 375 U.S. 836 (1963) (exposure to inflammatory headlines not sufficient); United States v. Feldman, 299 F.2d 914 (2d Cir.), cert. denied, 370 U.S. 910 (1962) (publicity did not contain detrimental statements).

${ }^{62}$ Cohen v. United States, 297 F.2d 760 (9th Cir.), cert .denied, 369 U.S. 865 (1962) (must show jurors read detrimental publicity, not merely that it was published). See cases cited notes 60-61 supra.

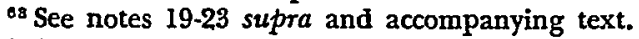

ou See notes 53-59 supra and accompanying text. 
partiality may be sufficient when the exposure occurs before the juror is impaneled and peremptory challenge is not employed to disqualify him. ${ }^{65}$ However, it would appear that fairness to the defendant requires that the sole influence upon the jury be evidence as presented during trial, particularly when evidence of the accused's bad character is involved. It is difficult to reconcile the exclusion of evidence at trial with the circumvention of the exclusionary rule which occurs when prejudicial information reaches the jury through extraneous sources. ${ }^{68}$

\section{Procedural Rights}

An accused is afforded certain constitutional safeguards during the course of the prosecution, including the right to the effective assistance of counsel at all significant steps in the proceeding. ${ }^{67}$ In addition, he must be informed of the specific charges against him. ${ }^{08}$ He has the right to be present during all siguificant stages of his trial, ${ }^{69}$ to confront and cross-examine his accusers, ${ }^{70}$ and to present

or See United States v. Shaffer, 291 F.2d 689, 694-95 (7th Cir.), cert. denied, 968 U.S. 915 (1961), wherein the defendants sought a reversal of their conviction on the basis of Marshall because of prejudicial publicity which occurred before the trial. The publicity which the court of appeals characterized as "prejudicial to the defendants" occurred the weekend before the impanelment of the jury. During voir dire examination five jurors admitted an awareness of the publicity, but the court of appeals held that Marshall did not apply since the defendants failed to use all their peremptory challenges despite the possibility of securing jurors who had not heard or seen the publicity.

* "The theory of our system is that the conclusions to be reached in a case will be induced only by evidence and argument in open court, and not by any outside influence, whether of private talk or public print." Patterson v. Colorado, 205 U.S. 454, 462 (1907) (Holmes, J.). See Marshall v. United States, 360 U.S. \$10, 312.13 (1959).

o7 See Miranda v. Arizona, 384 U.S. 436 (1966); Escobedo v. Illinois, 978 U.S. 478 (1964); Douglas v. California, 372 U.S. 353 (1963); Gideon v. Wainwright, 972 U.S. 935 (1963); Johnson v. Zerbst, 904 U.S. 458 (1938); Powell v. Alabama, 287 U.S. 45 (1932); Beaney, The Right to Counsel in American Courts 164-98 (1955); Beaney, The Right to Counsel: Past, Present, and Future, 49 VA. L. Rev. 1150 (1963); Bennctt, Right to Counsel-A Due Process Requirement, 23 LA. L. Rev. 662 (1963); Krash, The Right to a Lawyer: The Implications of Gideon v. Wainwright, 39 NOTRE DAME LAw. 150 (1964); Note, 49 VA. L. REV. 1531 (1968).

${ }^{88}$ Cole v. Arkansas, 939 U.S. 196 (1948).

09 Lewis v. United States, 146 U.S. 370 (1892).

${ }^{70}$ In three recent cases the Court held that the sixth amendment right to confrontation is extended through the due process clause of the fourteenth amendment to bind the states. Parker v. Gladden, 385-U.S. 369, 364 (1966) (per curiam); Douglas v. Alabama, 380 U.S. 415 (1965); Pointer v. Texas, 380 U.S. 400 (1965). This right applies only to the trial stage of the proceeding and does not extend to the presentence investigation by a judge, Williams v. New York, 937 U.S. 241 (1949), to the sanity hearing of an already convicted defendant, Solesbee v. Balkcum, 839 U.S. 
evidence in his own behalf. ${ }^{71}$ The effectiveness of these protections may be diminished, however, by the intrusion of prejudicial extraneous influences. Jurors may be exposed to material which is not presented at trial and which the defendant is not able to challenge. ${ }^{22}$ Charges not the subject of the prosecution may be made without the opportunity for a judicial denial and defense. ${ }^{73}$ Supposed witnesses may make damaging unsworn statements out of court without being subjected to cross-examination and confrontation..$^{74}$ Experience has shown that defense counsel ${ }^{75}$ as well as the prosecution $^{76}$ will resort to the use of extraneous influences to prejudice the case in their favor. Under these circumstances, the right to counsel is of little value unless counsel can act effectively to protect the accused's interests. ${ }^{77}$ The question of the guilt or innocence of an accused is a controversy to be decided not in the market place of ideas, but rather within the controlled conditions of a court of law.78 Therefore, fairness and impartiality would seem to require that only presentations at trial within the framework of the rights afforded the accused should be permitted to influence jurors. The impact of extraneous influences should not be gauged by whether or not they

9 (1950), or to probation and parole revocation proceedings. Escoe v. Zerbst, 295 U.S. 490 (1985) (dictum). See Kadish, Legal Norm and Discretion in the Police and Sentencing Processes, 75 HARv. L. REv. 904 (1962). In Jencks v. United States, 353 U.S. 657 (1957), the Court, under its federal supervisory power, held that the accused was entitled to see and inspect written reports of government undercover agents for the purpose of impeaching the latter's testimony. See Comment, 38 N.Y.U.L. REv. 1133 (1963).

71 See Powell v. Alabama, 287 U.S. 45, 58-59 (1982) and authorities cited therein.

72 See Parker v. Gladden, 385 U.S. 363 (1966) (per curiam); Sheppard v. Maxwell, 384 U.S. 333, 360-61 (1966).

${ }^{78}$ In People v. Hryciuk, 5 Ill.2d 176, 125 N.E.2d 61 (1954), the Illinois Supreme Court awarded a new trial to a prisoner who had been convicted of rape in a trial in which the jurors were not sequestered and during which two Chicago newspapers printed stories saying the defendant had, in addition to the crime with which he was charged, confessed to two murders and had assaulted some fifty women. But see McHenry v. United States, 276 Fed. 761 (D.C. Cir. 1921).

" See Sheppard v. Maxwell, 384 U.S. 333, 361 (1966); cf. Parker v. Gladden, 385 U.S. 363 (1966) (per curiam).

${ }^{75}$ See United States ex rel. Bloeth v. Denno, 313 F.2d 364, 378-79 (2d Cir.) (dissenting opinion), cert. denied, 372 U.S. 978 (1963) (criticizes defense's use of publicity to aid a plea of insanity); Foreman, $A$ Free Press and a Fair Trial-A Defense Attorney's View, 11 Vir.. L. REv. 704, 705-06 (1966); Lofton, Justice and the Press-Communication Inside and Outside the Courtroom, 6 ST. Lours L.J. 449, 479 (1961).

${ }^{70}$ See Stroble v. California, 343 U.S. 181, 191-95 (1952); notes 38 supra and 206 infra and accompanying text. See generally Lofton, supro note 75, at 457-60.

${ }^{77}$ See notes 36,58 supra and accompanying text.

${ }^{\text {is }}$ See note 66 supra. 
are subsequently admitted into evidence, ${ }^{79}$ for such a test would be governed by hindsight and the mere fortuity that certain evidence may later be admitted. More importantly, the protections available at trial will not be available at other instances of exposure, especially the initial exposure, when such safeguards may be most necessary. ${ }^{80}$

\section{Judicial Setting}

The purpose of a trial "is to provide a fair and reliable determination of guilt."81 The guarantee of a public trial has been construed to preclude a secret trial and its attendant vices, ${ }^{82}$ but this privilege of the accused is not license for a public spectacle. ${ }^{83}$ The accused is entitled to be tried in a judicially serene atmosphere, ${ }^{84}$ and although this requirement has not yet been strictly delineated, it now has at least two facets. First, disruptive influences which prevent the orderly administration of justice are not permitted; ${ }^{85}$ thus, noise and commotion, ${ }^{86}$ a carnival atmosphere, ${ }^{87}$ and mob violence ${ }^{88}$ must

${ }^{70}$ See Jaffe, The Press and the Oppressed-Part II, 56 J. CRIM. L., C. \& P.S. 158, 166 (1965); Jaffe, Trial by Newspaper, 40 N.Y.U.L. REv. 504, 524 (1965). But see Stroble v. California, 343 U.S. 181, 193 (1952).

${ }^{80}$ See notes 36,58 supra and accompanying text.

81 Estes v. Texas, 381 U.S. 532, 564 (1965) (Warren, C.J., concurring).

82. In re Oliver, 393 U.S. 257, 266-73 (1948).

${ }^{88}$ See Estes v. Texas, 381 U.S. 532, 570-7I (1965) (Warren, C. J., concurring); Ridcau v. Louisiana, 373 U.S. 723, 726 (1963). In Roberts v. State, 100 Neb. 199, 158 N.W. 930 (1916), a conviction was reversed where the trial was moved from the courtroom to a local theater to accommodate the crowds. See generally Estes v. Texas, supra at 572-78 (Warren, C.J., concurring); Hallam, Some Object Lesssons on Publicity in Criminal Trials, 24 MiNn. L. REv. 453, 456-62 (1940); 49 ColuM. L. REv. 110 (1949).

s4 See Sheppard v. Maxwell, 384 U.S. 338, 355 (1966); Estes v. Texas, supra note 83 at 536; cf. Turner v. Louisiana, 379 U.S. 466, 472 (1965); Cox v. Louisiana, 379 U.S. 559, 562 (1965); Wood v. Georgia, 370 U.S. 375, 383 (1962).

${ }^{85}$ See Sheppard v. Maxwell, supra note 84 , at 344 , where because of the closeness and number of reporters inside the bar Sheppard's attorney was unable to confer with his client or the judge without being overheard by the press who subsequently printed these conversations in newspapers to which the jurors had access.

so See Sheppard v. Maxwell, supra note 85, at 355; Estes v. Texas, 381 U.S. 582, 536 (1965).

${ }_{87}$ "The carnival atmosphere at trial could easily have been avoided since the courtroom and courthouse premises are subject to the control of the court." Sheppard v. Maxwell, 384 U.S. 333 , 358 (1966).

The Court criticized the arrangements the trial judge made to accommodate the press, such as placing a temporary table for the press inside the bar, assigning most of the seats in the courtroom to the press, allowing a radio station to use a room next to the jury room for its broadcasting equipment, permitting the press to photograph cxtensively not only Sheppard but also the jury and the judge himself, and failing to control the commotion and noise occasioned by the press. Id. at 355 .

This situation is to be contrasted with the conduct of the second trial, at which only Cleveland papers were assigned seats in the courtroom. The out-of-town papers had to wait in line with the rest of the spectators to secure admission. It is interesting 
be excluded. Second, subtle extraneous influences which might interfere with the reliable determination of guilt are not tolerated; hence, the probing eye of the television camera is prohibited, ${ }^{89}$ as are undue pressures on the jurors. ${ }^{90}$ In the cases which have dealt with the element of judicial serenity no specific showing of prejudice was required, nor were the statements of impartiality made by the jurors sufficient to prevent reversal.91 The intrusion of these extraneous influences alone was held sufficient to deny the accused his constitutionally guaranteed fair trial. ${ }^{92}$

to note that Sheppard's defense counsel, F. Lee Bailey, objected to these stringent procedures on the ground that they deprived the defendant of his constitutional right to a public trial. See N.Y. Times, Nov. 15, 1966, p. 29, col. 1 .

as Moore v. Dempsey, 261 U.S. 86, 90-91 (1923); Frank v. Mangum, 237 U.S. 309, 347 (1915) (Holmes, J., dissenting).

${ }^{80}$ In Estes v. Texas, 381 U.S. 352 (1965), only four Justices, Clark, Warren, Douglas, and Goldberg, stated that they would ban television permanently from criminal trials. Mr. Justice Harlan voted to reverse only on the specific facts of the case. Id. at 596 . The precedential value of Estes is therefore uncertain. The opinion of the Court by Mr. Justice Clark found television objectionable on several grounds: (1) it improperly influences jurors by emphasizing the notoriety of the trial, affects their impartial judgment, distracts their attention, facilitates (when not sequestered) their watching parts of the trial, and improperly influences prospective jurors and, thus, endangers the fairness of a new trial; (2) it impairs the testimony of witnesses, causing some individuals to be frightened and reticent and others to overstate their testimony, thus frustrating the practice which excludes witnesses from the courtroom except while testifying; (3) it distracts judges generally and may have a pernicious effect upon those who are elected; (4) it imposes undue pressnres on the defendant and intrudes into the confidential attorney-client relationship. $Y d$. at 544-50. In one concurring opinion televising the trial was objected to on three grounds: (1) it deviates from the purpose of a trial and adversely affects the trial participants; (2) it gives the public the wrong impression of a trial; (3) it exposes only certain defendants to prejudicial conditions. Id. at 565 (Warren, C.J., concurring). The other concurring Justice stated that television is not per se detrimental, but the manner in which it is used may render it improper in a particular case. Id. at 596 (Harlan, J., concurring).

${ }^{90}$ For example, jurors may be subject to intense community pressure to reach a desired verdict. See Meyer v. Cadwalader, 49 Fed. 32 (C.C.E.D. Pa. 1891); Lofton, supra note 75, at 475-77; Comment, 38 So. CAL. L. Rev. 672, 681 (1965). A most flagrant example of community pressure was described by Mr. Justice Holmes in Moore v. Dempsey, 261 U.S. 86, 91 (1923), where he stated that as a result of the threat of mob violence the "counsel, jury and judge were swept to the fatal end by an irrestible wave of public passion ...."

Several notable cases have found prejudice in more subtle influence. Speaking of the effect of television cameras on jurors and witnesses the Supreme Court stated: "There is hittle wonder that the defendant cannot 'prove' the existence of such factors. Yet we all know from experience that they exist." Estes v. Texas, 381 U.S. 532, 547 (1965). Similarly the court found "extreme prejudice inherent" in the association of sequestered jurors with the prosecution's chief witnesses, Turner v. Louisiana, 379 U.S. 466,473 (1965), and a presumption of prejudice was raised by unauthorized communication with jurors by bailiffs, Parker v. Gladden, 385 U.S. 363 (1966) (per curiam).

${ }^{91}$ See Sheppard v. Maxwell, 384 U.S. 333, 352-55 (1966); Estes v. Texas, supra note 90, at 542-43; Turner v. Louisiana, supra note 90, at 471-74.

${ }^{02}$ See cases cited note 91 supra. 


\section{PROPOSED METhODS OF CONTROL}

Most of the recent commentary dealing with prejudicial extraneous influences and criminal justice has been concerned primarily with the "fair trial-free press" controversy. ${ }^{93}$ Various methods of eliminating or controlling prejudicial extraneous influences have been criticized as interfering with the freedoms of press and speech, ${ }^{94}$ the right to a public trial, ${ }^{95}$ and the public "need to know." ${ }^{98}$ This discussion will evaluate certain proposed methods of control in the context of such competing considerations, with particular reference to the rights of the accused which in the aggregate constitute the fairness which these methods seek to ensure. For purposes of analysis the proposed methods will be considered within three classiflcations: post-trial judicial relief; remedies available at the trial level; and, the most controversial, antidissemination or non. disclosure techniques. In view of its timeliness, thoroughness and prestige, the Tentative Draft of Standards of the American Bar Association's Advisory Committee on Fair Trial and Free Press ${ }^{97}$

${ }^{08}$ E.g., Daniel, Fair Trial and Freedom of the Press, Case \& Com., Sept.-Oct. 1966, p. 3; Goldfarb, Public Information, Criminal Trial and the Cause Celebre, 36 N.Y.U.X. Rev. 810 (1961); Hudon, Freedom of the Press Versus Fair Trial: The Remedy Lies with the Courts, 1 VALParaiso L. REv. 8 (1966); Jaffe, The Press and the Oppressed (Parts I-II), 56 J. CRIM. L., C. \& P.S. 1, 158 (1965); Jaffe, Trial by Newspaper, 40 N.Y.U.L. REv. 504 (1965); Lofton, Justice and the Press-Communication Inside and Outside the Courtroom, 6 ST. Lovis L.J. 449 (1961); Mueller, Problem Posed by Pub. licity to Crime and Criminal Proceedings, 110 U. PA. L. REv. 1 (1961); Otterbourg, Fair Trial and Free Press: $A$ New Look in 1954, 40 A.B.A.J. 838 (1954); Royster, The Free Press \& a Fair Trial, 43 N.C.l Rev. 365 (1965); Segal, Fair Trial and Free Press-An Analysis of the Problem, 51 Mass. L.Q. 101 (1966); Wiggins, The Press and Conflicts of Interest, 24 FED. B.J. 358 (1964); Wiggins, The Public's Right to Public Trial, 19 F.R.D. 25 (1957); Will, Free Press vs. Fair Trial, 12 DePaul L. REv. 197 (1963); Wright, Fair Trial-Free Press, 38 F.R.D. 435 (1966); Symposium-Free Press and a Fair Trial, Il VıL. L. REv. 677 (1966).

'See Daniel, supra note 93, at 4,6; Mueller, supra note 93, at 24; Wiggins, The Press and Conficts of Interest, 24 FED. B. J. 358, 360-65 (1964).

os 49 Colum. L. Rev. 110 (1949). See generally Radin, The Right to a Public Triäl, 6 TEMP. L.Q. 381 (1932).

${ }^{\circ 6}$ See Daniel, supra note 93, at 4, 6; Wright, supra note 93, at 435 . D. T. Bryan, American Newspaper Publisher Association Free Press and Fair Trial Committee Chairman, has warned against any steps that would deprive the public of information it needs, such as reports of criminal activities and trials. N.Y. Times, Oct. 2, 1966, p. 1, col. 2.

${ }^{7}$ aba advisory Committee on fair Trial and Free Press, Standards Relating to Fair Trial and Free Press (Tent. Draft Dec. 1966) [hereinafter cited as Standards]. The STANDards have occasioned a great deal of comment, to a large degree unfavorable. See N.Y. Times, Oct. 2, 1966, p. 1, col. 2 (D. T. Bryan, A.N.P.A. Free Press and Fair Trial Committee Chairman); id., Oct. 4, 1966, p. 26, col. 1 (Judge G. C. Edwards, urges voluntary controls); id., Oct. 5, 1966, p. 43, col. 1 (W. B. Dickinson, Pres., A. P. 
will be given primary consideration in discussing the trial level and antidissemination remedies.

\section{Post-TRIAL}

While the implementation of some remedial steps may be far removed from the appellate courts, the ultimate responsibility to determine whether or not there has been a "fair trial" will rest upon these tribunals. ${ }^{98}$ Although the Standards recmomend that their nondisclosure provisions be implemented by revision of the Canons of Professional Ethics ${ }^{99}$ or local court rules, ${ }^{100}$ even here the courts would have to adjudicate questions arising from alleged breaches of such codes and rules and would have to determine the permissible sanctions. ${ }^{101}$

In discussing the impact of prejudicial extraneous influences the Supreme Court has indicated that "trial courts must take strong measures to ensure that the balance [between unrestrained news reporting and an impartially rendered decision] is never weighed against the accused," 102 and that "appellate tribunals have the duty to make an independent evaluation of the circumstances." ${ }^{103}$ Several new approaches may be taken on appellate review to implement this defendant-oriented standard. ${ }^{104}$ For example, on appeal the discretionary decisions of the trial judiciary ${ }^{105}$ might be subjected to a more rigorous test than that of United States $v$. Reynolds, ${ }^{106}$ which requires reversal only upon a showing of "manifest error."107 In

Managing Eds. Ass'n; Police Chiefs also voice opposition); id., Oct. 6, 1966, p. 30, col. 1 (C.B.S. Pres. Stanton); id., Oct. 9, 1966, p. 89, col. 2 (thirteen out of fourteen newspaper editors polled see A.B.A. proposals as curbing press freedom). But see $i d$., Oct. 9, 1966, p. 89, col. 2 (B. Hawthorne, Editor of Minnesota Star \& Tribune states that A.B.A. proposals would not bar responsible coverage of crime news).

${ }^{88}$ The STANDARDS themselves are not directed specifically to appellate tribunals. See STANDARDs 1-2. Their assistance in this regard is limited to a demonstration and documentation of the problems and of the need for reform.

${ }^{\circ}$ Id. $\$ 1.1$.

$100 \mathrm{Id}$. $\S \S 1.2,2.1, .3$.

${ }^{101}$ See id. §§ 1.3, 2.3; In re Sawyer, 360 U.S. 622 (1959); Mack Appeal, 386 Pa. 251, 126 A.2d 679 (1956), cert. denied, 352 U.S. 1002 (1957), 105 U. PA. L. REv. 749 (1957). ${ }^{102}$ Sheppard v. Maxwell, 384 U.S. 333, 362 (1966).

103 Ibid.

104 Defendant-oriented appellate review has been thought to offer an adequate solution to the entire problem of extraneous influences. See Hudon, supra note 93, at 3839. But see Comment, 33 U. CHI. L. REv. 512 (1966).

${ }^{105}$ See notes 121-25 infra and accompanying text.

10898 U.S. 145 (1878). See notes 15-23 supra and accompanying text:

20798 U.S. at 156. One suggested solution to the problem of ensuring a fair trial 
order more fully to protect the rights of defendants, appellate courts might also extend the applicability of the "inherent danger of prejudice" test which seems to have been adopted by the Supreme Court in several recent decisions. ${ }^{108}$ In each of these cases no actual prejudice to the accused was established, ${ }^{109}$ but the Court found that the particular practice in question held such an inherent danger of prejudice that the conviction could not be upheld. ${ }^{110}$

The suggestion of a defendant-oriented standard of review is particularly relevant to the appellate practice of invoking the doctrine of waiver where a defendant has failed to exhaust all of the standard procedural remedies at trial. Waiver has been invoked in cases in which the defendant had failed to seek a continuance, ${ }^{111}$ request a change of venue, ${ }^{112}$ engage in extensive voir dire examina-

advocates curtailment of the trial judge's discretion by requiring him to grant a new trial automatically whenever specific statutory or judicially established criteria were shown to be present. See Comment, 33 U. CHI. L. REv. 512, 523 (1966).

${ }^{108}$ See Parker v. Gladden, 385 U.S. 363, 365-66 (1966) (per curiam) (unauthorized communication by bailiff to jurors); Sheppard v. Maxwell, 384 U.S. 333, 350-52 (1966) (prejudicial publicity and conduct of trial); Estes v. Texas, 381 U.S. 532, 542-43 (1965) (televising of trial and pre-trial hearings); Turner v. Louisiana, 379 U.S. 466, 473 (1965) (use of prosecution witnesses as bailiffs for sequestered jury); Rideau v. Louisi. ana, 373 U.S. 723, 726-27 (1963) (pre-trial televising of "confession"); Marshall v. United States, 360 U.S. 310 (1959) (per curiam) (exposure of jurors during trial to newspaper account of inadmissible criminal record). But see Holt v. United States, 218 U.S. 245 (1910).

${ }^{100}$ See cases cited note 108 supra. The decisions were reached either as matters of constitutional law or in the exercise of supervisory power over the federal judiciary. The important point to note, however, is not the basis for the decisions but the underlying approach evidenced therein. See note 18 supra and accompanying text.

${ }^{110}$ See cases cited note 108 supra. The inherent danger of prejudice test is a substantial departure from the traditional demand for a showing of specific harm. See note 18 supra and accompanying text. Indeed, several earlier Supreme Court decisions have denied relief in situations where the inherent danger test would seem appropriate, since no specific harm was established. See Beck v. Washington, 369 U.S. 541, 555-58 (1962) (national televising of congressional hearings aecusing Beck of misconduct); United States ex rel. Darcy v. Handy, 351 U.S. 454, 462-63 (1956) (preju. dicial pre-trial publicity); Stroble v. California, 343 U.S. 181, 191-95 (1952) (same).

${ }^{111}$ See United States ex rel. Darcy v. Handy, supra note 110, at 462-63; United States v. Milanovich, 303 F.2d 626, 629 (4th Cir.), cert. denied, 371 U.S. 876 (1962); Palakiko v. Harper, 209 F.2d 75, $97-98$ (9th Cir. 1953), cert. denied, 347 U.S. 956 (1954); United States v. Rosenberg, 200 F.2d 666, 668-69 (2d Cir. 1952), cert. denied, 345 U.S. 965 (1953).

${ }^{112}$ See United States ex rel. Darcy v. Handy, supra note 111, at 463; Stroble v. California, 343 U.S. 181, 193-94 (1952); Latham v. Crouse, 320 F.2d 120, 123 (10th Cir. 1963); United States v. Milanovich, supra note I1I, at 629; Finnegan v. Untied States, 204 F.2d 105, 110 (8th Cir.), cert. denied, 346 U.S. 821 (1953); United States v. Ragen, 146 F.2d 349, 352 (7th Cir.), cert. denied sub nom. Bongiorno v. United States, 325 U.S. 865 (1945). 
tion, ${ }^{113}$ exhaust peremptory challenges, ${ }^{114}$ challenge individual jurors for cause, ${ }^{115}$ challenge the whole jury panel, 116 or raise the issue of pre-trial publicity at the outset of the trial.117 The theory underlying the waiver doctrine is that the accused should not be heard to complain that his trial was unfair when he has not exhausted the methods provided by law to ensure fairness. ${ }^{118}$ However, the real goals of a voluntary waiver doctrine, the rational election of known alternatives ${ }^{119}$ and the prevention of specious appeals, ${ }^{120}$ may be achieved by alert trial judges. Whenever the question of possible prejudice arises, such as by widespread publicity of pre-trial events or the exposure of a juror to illicit pressure, the trial judge should be required to ascertain the views of the accused, through counsel, and of the prosecution, and to append their responses to his decision and finding of fact as to the existence of prejudice. The doctrine of waiver would then be applied by appellate courts only in cases in which there had been a voluntary election by the accused.

\section{TRIAL}

Traditionally, the burden of ensuring fairness in notorious cases has been borne by the discretionary remedies administered by the

${ }^{118}$ See United States v. Sorce, 308 F.2d 299, 301 (4th Cir. 1962), cert. denied, 377 U.S. 957 (1964); United States v. Shaffer, 291 F.2d 689, 694-95 (7th Cir.), cert. denied sub nom. Share v. United States, 368 U.S. 914 (1961).

21" See United States ex rel. Darcy v. Handy, 351 U.S. 454, 463 (1956); United States v. Milanovich, 303 F.2d 626, 629 (4th Cir.), cert. denied, 371 U.S. 876 (1962); United States v. Shaffer, supra note 113, at 695; United States v. Moran, 236 F.2d 361, 362 (2d Cir.), cert. denied, 352 U.S. 909 (I956); United States v. Rosenberg, 200 F.2d 666, 668-69 (2d Cir. 1952), cert. denied, 345 U.S. 965 (1953).

${ }^{110}$ See Beck v. Washington, 369 U.S. 541, 557-58 (1962); Rizzo v. United States, -304 F.2d 810 (8th Cir.), cert. denied sub nom. Nafie v. United States, 371 U.S. 890 (1962); United States v. Beadon, 49 F.2d 164, 166 (2d Cir.), cert. denied, 284 U.S. 625 (1931).

${ }^{120}$ See Blumenfield v. United States, 284 F.2d 46, 51-52 (8th Cir. 1960), cert. denied, 365 U.S. 812 (196I).

${ }^{217}$ See United States ex rel. Darcy v. Handy, 351 U.S. 454, 463 (1956); Stroble v. California, 343 U.S. 181, 194-95 (1952).

${ }^{218}$ See Address by J. R. Thompson, Ass't State's Att'y of Cook County, in InBAu \& Sowle, Cases on Criminal Justice 1092 (2d ed. 1964). But see Geagan v. Gavin, 292 F.2d 244, 246 (1st Cir. 1961), cert. denied, 370 U.S. 903 (1962); Delaney v. United States, 199 F.2d 107, 116 (1st Cir. 1952).

${ }^{210}$ Rand v. Morse, 289 Fed. 339, 344 (8th Cir. 1923). The broad application of the waiver doctrine in the area of fair trial seems anomalous since " courts indulge every reasonable presumption against waiver' of fundamental constitutional rights and ... 'do not presume acquiescence in the loss of fundamental rights.' " Johnson v. Zerbst, 304 U.S. 458, 464 (1988) ; accord, Carnley v. Cochran, 369 U.S. 506 (1962).

${ }^{120}$ See United States v. Rosenberg, 200 F.2d 666, 669-70 (2d Cir. 1952), cert. denied, 345 U.S. 965 (1953). 
trial judiciary. These include voir dire examination, challenge of veniremen, change of venue, continuance, cautionary instructions, sequestration, mid-trial examination of jurors, waiver of jury trial, grant of mistrial, and setting aside a verdict of guilty. However, such remedies have generally been considered to provide inadequate protection for defendants in cases where public interest and emotions are high.121

The Standards predicate broad reform of the administration of these remedies ${ }^{122}$ upon a change in the underlying principle of application. Most trial judges seem to have employed the remedies sparingly, ${ }^{123}$ as extraordinary measures compelled only by a showing that actual harm would result were they withheld, at times basing denial on the belief that the requested relief would not correct an admittedly undesirable situation. ${ }^{124}$ Some commentators have sug. gested that trial judges are loath to admit the need for such remedies because they feel it reflects on their ability to ensure fairness in their own tribunals. ${ }^{125}$ As a practical matter, the courts have often held in abeyance the granting of a change of venue or continuance until voir dire examination on the theory that the latter provides the best test for the ascertainment of community hostility. ${ }^{126}$ The Standards would change the basis upon which these trial level remedies would be invoked from a showing of actual harm to a showing of reasonable likelihood of prejudice ${ }^{127}$ and would allow qualified opinion surveys as well as affidavits and opinion testimony as evidence on

${ }^{121}$ See Jaffee, The Press and the Oppressed-Part I, 56 J. Crim. L., C. \& P.S. I, 11-12 (1965); Comment, 51 CoRnell L.Q. 306, 313-17 (1966); Note, 60 Colum. L. Rev. 349 , 375-80 (1960). But see Wright, supra note 93, at 437 .

122 STANDARDS $\$ \S 3.2-.6$.

${ }^{128}$ See Address by J. R. Thompson, Ass't State's Att'y of Cook County, in INraU \& Sowle, CAses on Criminal Justice 1092-93 (2d ed. 1964); Will, supra note 93, at 209; Comment, 33 U. CHr. L. Rev. 512, 515 (1966).

${ }^{126}$ Rees v. Peyton, 341 F.2d 859, 863 (4th Cir. 1965) (change of venue held useless because publicity reached entire state); United States v. Dioguardi, 20 F.R.D. 33, 35-36 (S.D.N.Y. 1956) (change of venue denied, partially because entire country exposed to incident).

${ }^{225}$ See Austin, Prejudice and Change of Venue, 68 Drck. L. REv. 401, 408 (1964); Comment, 33 U. Chr. L. REv. 512, 515 (1966).

120 See, e.g., United States v. Hoffa, 156 F. Supp. 495, 499 (S.D.N.Y. 1957) (motion for continuance denied); United States v. Dioguardi, 20 F.R.D. 33, 36 (S.D.N.Y. 1956) (motion for a change of venue denied); United States v. Carper, 13 F.R.D. 483, 487 (D.D.C. 1953) (same); United States v. Eisler, 75 F. Supp. 634, 639 (D.D.C. 1947) (same). But see Broeder, Voir Dire Examinations: An Empirical Study, 38 So. Cal. L. REv. 503, 505 (1965).

127 STANDARDS $\$ 3.2$ (c). 
motions for relief. ${ }^{128}$ Upon a showing of reasonable likelihood of prejudice, the requested remedy would be granted. ${ }^{120}$

\section{Change of Venue}

The Standards would permit a change of venue upon motion of the accused or the prosecution whenever dissemination of potentially prejudicial material makes it reasonably likely that a fair trial could not be secured without such relief. ${ }^{130}$ The change could be granted at any time up to the taking of evidence, allowing more than one move if necessary. ${ }^{131}$

Change of venue has been criticized on several grounds. In the first instance, it forces an accused to forfeit his right to a local trial in the hope of gaining a fair trial, which is also his right. ${ }^{132}$ Furthermore, in many notorious trials the potential prejudice has spread far beyond the local level, encompassing an entire state or even the nation. ${ }^{133}$ However, it is likely that in most cases the danger will be of differing degrees, decreasing at least slightly in

${ }^{128}$ Id. $\$ 3.2$ (b). The case law has generally excluded opinion polls on the ground of hearsay or unreliability. See, e.g., Irvin v. State, 66 So. $2 d 288$ (Fla. 1953), cert. denied, 346 U.S. 927 (1954). But see State v. Lupino, 268 Minn. 344, 129 N.W.2d 294 (1964), cert. denied, 379 U.S. 978 (1965). A number of commentators have suggested that the use of opinion polls would furnish a more scientific basis for ascertaining community sentiment, and that comparisons could then be made with the sentiment in other communities in the jurisdiction. See Goldfarb, supra note 93, at 837; Note, 66 Harv. L. REv. 498, 508-10 (1953); Comment, 33 U. CH. L. REv. 512, 527 (1966).

${ }^{220}$ STANDARDS $\$ 3.2$ (c). "Reasonable likelihood" is to be determined by use of several factors, one of which is the opinion of the trial judge. Ibid.

${ }^{180} I d$. $\$ 3.2$ (a). Thus, for example, the state would have been granted change of venue in the infamous 1965 civil rights cases in Haynesville, Alabama, because of the local prejudice against the victims and in favor of the accused Klansmen. On voir dire in one of these trials each venireman expressed the belief that the victims were inferior. Address by Honorable Richmond Flowers to Duke Bar Ass'n, Nov. 30, 1966. See generally Note, 60 Colum. L. REv. 349, 360-65 (1960) (compilation of the state statutes for change of venue and their interpretation).

131 Standards $\$ 3.2$ (e). In Irvin v. Dowd, 366 U.S. 7I7 (1961), the problem of statutory limitations upon change of venue was recognized since Indiana law permits only one such change. IND. STAT. ANN. \$9-1305 (1956). However, the question was not resolved in Irvin since the Indiana Supreme Court in State ex rel. Gannon v. Porter Circuit Court, 239 Ind. 637, 642, 159 N.E.2d 713, 715 (1959), had stated that "it becomes the duty of the judiciary to provide to every accused a public trial by an impartial jury, even though to do so the court must grant a second change of venue and thus contravene the general legislative policy of granting only one change of venue from the county."

${ }^{132}$ E.g., Address by J. R. Thompson, Ass't State's Att'y of Cook County, in INBAU \& Sowle, Cases on Criminal Justice 1092 (2d ed. 1964); Jaffe, Trial by Newspaper, 40 N.Y.U.L. REv. 504, 517 (1965); Comment, 51 CoRNeLL L.Q. 306, 314 (1966).

${ }^{138}$ E.g., Sheppard v. Maxwell, 384 U.S. 333 (1966); United States v. Dioguardi, 20 F.R.D. 33, 35 (S.D.N.Y. 1956). 
more remote areas. ${ }^{134}$ Change of venue has also been criticized as a costly and inconvenient device, ${ }^{135}$ although the relevance of such arguments to the rights of an accused is questionable.

\section{Continuance}

Continuance involves many of the same considerations as change of venue. It too requires the waiver of one right, that to a speedy trial, in quest of fairness. ${ }^{136}$ In situations in which bail cannot be met, moreover, the cost to the accused in terms of additional pretrial confinement seems especially high. Furthermore, there may be no assurance that prejudice will abate with the passage of time. ${ }^{137}$ However, where the potential prejudice seems to derive principally from public reaction to the commission of the crime, rather than from extensive dissemination of material relating to the actual proceedings, continuance would seem to be a particularly appropriate remedy. ${ }^{138}$ The Standards would condition the grant of a continuance upon satisfaction of the same requirements which are imposed for a change of venue. ${ }^{13 \theta}$

\section{Jury Selection}

Under the rubric of jury selection the Standards deal with challenges, the voir dire examination, and the use of panels selected from outside the district. ${ }^{140}$ Proof of a reasonable likelihood of prejudice would require a grant of the requested relief unless the judge were convinced that the danger did not in fact exist.

The voir dire examination is one of the most frequently and harshly castigated of the trial level remedies. It has been con-

\footnotetext{
${ }^{136}$ See STANDARDS 119-28 and cases cited therein.

${ }^{135}$ See Meyer, Free Press v. Fair Trial: The Judge's View, 41 N.D.L. REv. 14, 17 (1964); Comment, 51 Cornerl L.Q. 306, 314 (1966). See also United States v. Bonanno, 177 F. Supp. 106, 122 (S.D.N.Y. 1959), rev'd on other grounds, 285 F.2d 408 (2d Cir. 1960) (expense and inconvenience to the state mentioned as factors in considering venue change).

${ }^{130}$ See Address by J. R. Thompson, Ass't State's Att'y of Cook County, in Inbau \&. Soivle, Cases on Criminal Justice 1092 (2d ed. 1964); Meyer, supra note 135, at 17; Comment, 51 CORNell L.Q. 306, 314 (1966).

${ }^{137}$ See Delaney v. United States, 199 F.2d 107, 119 (1st Cir. 1952) (conviction reversed for failure to grant continuance of sufficient duration).

${ }^{188}$ See United States ex rel. Bongiorno v. Ragen, 54 F. Supp. 973, 976 (N.D. Ill. 1944), aff'd, 146 F.2d 349 (7th Cir.), cert. denied, 325 U.S. 865 (1945) (newspaper stories related to crimes, but no reference to defendant's case).

${ }^{139}$ STANDARDS $\$ 3.2$.

${ }^{110}$ Id. § 3.4 .
} 
tended, based on psychological studies ${ }^{141}$ and judicial reasoning, ${ }^{142}$ that the basic premise of voir dire, that a venireman can and will make accurate responses as to his mental processes, is unsound. Thus, several recent cases have abandoned the general practice and have reversed convictions despite uncontradicted avowals by jurors that they would strictly comply with instructions ${ }^{143}$ or were not tainted by extraneous matters. ${ }^{144}$

The methods presently used on voir dire often prevent the examination from fulfilling its purpose of impaneling impartial jurors. The Standards suggest that jurors be questioned singly and separately to preclude contamination of the group by the prejudicial disclosures of a single juror and to encourage candor by obviating group pressure to make answers conform to the responses desired. ${ }^{145}$ In examining prospective jurors, defense counsel is frequently forced to disclose the very matter he hopes is unknown in his attempts to discover bias. In addition, questions are often posed in a manner such that the desired response is not only clearly shown, but encouraged. ${ }^{146}$ While the Standards do not contain the proposal, it

\footnotetext{
141 Broeder, supra note 126 , at $510-15$.

${ }^{142}$ Delaney v. United States, 199 F.2d 107, 112-13 (1st Cir. 1952); Stroble v. California, 343 U.S. 181, 201 (1952) (Frankfurter, J., dissenting).

${ }^{148}$ See Marshall v. United States, 360 U.S. 310, 312-13 (1959); Delaney v. United States, supra note 142, at 116. But see Northern Cal. Pharmaceutical Ass'n v. United States, 306 F.2d 379, 383 (9th Cir.), cert. denied, 371 U.S. 862 (1962); Callanan v. United States, 223 F.2d 171, 177 (8th Cir.), cert. denied, 350 U.S. 862 (1955); Bianchi v. United States, 219 F.2d 182, 191 (8th Cir.), cert. denied, 349 U.S. 915 (1955); Finnegan v. United States, 204 F.2d 105, 110 (8th Cir.), cert. denied, 346 U.S. 821 (1953); Centuni v. United States, 69 F.2d 624, 625 (9th Cir. 1934); United States ex rel. Burke v. Denno, 148 F. Supp. 498, 500-03 (S.D.N.Y. 1957), aff'd per curiam, 243 F.2d 835 (2d Cir.), cert. denied, 355 U.S. 849 (1957).

14 See Irvin v. Dowd, 366 U.S. 717 (1961); United States ex rel. Bloeth v. Denno, 313 F.2d 364 (2d Cir.), cert. denied, 372 U.S. 978 (1963); Juelich v. United States, 214 F.2d 950 (5th Cir. 1954); Delaney v. United States, supra note 143. But see Thiede v. Utah, 159 U.S. 510 (1895); Spies v. Illinois, 123 U.S. 131 (1887); Hopt v. Utah, 120 U.S. 430 (1887); Bearden v. United States, 320 F.2d 99 (5th Cir. 1963), cert. denied, 376 U.S. 922 (1964); Rizzo v. United States, 304 F.2d 810 (8th Cir.), cert. denied, 371 U.S. 890 (1962); Geagan v. Gavin, 292 F.2d 244 (Ist Cir. 1961), cert. denied, 370 U.S. 903 (1962); Hawkins v. United States, 116 Fed. 569 (9th Cir. 1902); Gallot v. United States, 87 Fed. 446 (5th Cir. 1898).

${ }^{165}$ STANDARDS. $\$ 3.4$ (a). See id. 130-38. Compare Paschal v. United States, 306 F.2d 398 (5th Cir. 1962).

1"S Thus one judge, before asking whether any juror had a fixed opinion, stated: "Now, a fixed opinion, gentlemen, means a buttheaded opinion .... It means the kind of buttheadedness that you would find in a man with a head the shape of a baseball. Don't ever try to argue with him. He has an opinion on everything, and if God could speak out of heaven to him, it would have no effect on his opinion." Fuller v. State, 269 Ala. 312, 319, 113 So. $2 d$ 153, 158 (1959).
} 
would seem desirable that the questions be neutrally phrased to avoid disclosing that which it is hoped is unknown. ${ }^{147}$ Moreover, the examination might be conducted with a standard list of questions dealing with possible knowledge of such prejudicial matters as incriminating statements allegedly made by the accused and the accused's prior criminal record. The questioning would be prefaced by the statement that these were standard questions requested by neither side but required by fairness to both and that they in no way implied the existence of any such information. Under any form of questioning, disclosure of the venireman's views rather than the duty of impartiality must be stressed. ${ }^{148}$

The standard upon which potential jurors may withstand challenge for cause is presently the avowed ability to lay aside any preconceptions of guilt or innocence of the accused. ${ }^{140}$ Just as several recent cases have questioned this standard, stating that it places an impossible burden of self-analysis on veniremen, ${ }^{150}$ the Standards suggest closer scrutiny. Challenges would be granted much more liberally, based on the extent and type of exposure to prejudicial matter and the state of mind evidenced by the venireman. Whenever either the admitted state of mind or the extent or type of exposure raises a siguificant possibility of bias, a challenge for cause would be sustained. ${ }^{151}$ When the injection of potentially prejudicial matter into the proceeding raises a serious possibility of juror bias during trial, the Standards suggest an inquiry similar to that on voir dire. ${ }^{152}$ The method of questioning and the standard for ex-

\footnotetext{
${ }^{112}$ See Krogman v. United States, 225 F.2d 220, 228-29 (6th Cir. 1955).

${ }^{148}$ See StANDARDS $\$ 3.4$ (a).

${ }^{149}$ See Reynolds v. United States, 98 U.S. 145 (1878); notes 15-18 supra and accompanying text.

${ }_{180}$ See Irvin v. Dowd, 366 U.S. 717, 727-28 (1961); Delaney v. United States, 199 F.2d 107, 112-13 (lst Cir. 1952).

${ }_{151}$ StANDARDS $\$ 3.4(\mathrm{~b})$. Although challenges provide a method of juror rejection rather than juror selection, Hays v. Missouri, 120 U.S. 68, 71 (1887), the entire process of jury selection has been felt to afford protection to the accused sufficient to obviate the need for restrictions on dissemination. See Comment, 51 CorNell L.Q. 306, 32527 (1966).

152 StANDARDS $\$ 3.5(f)$. But see Hilliard v. Arizona, 362 F.2d 908 9th Cir. 1966). Here again, when the jury is polled, intimidating questions or questions which indicate a desired answer should be avoided. For example in Smith v. United States, 236 F.2d 260 (8th Cir.), cert. denied, 352 U.S. 909 (1956), a prejudicial article was published after cautionary instructions had been given. Upon defense counsel's request that, despite the instructions, the jury be polled as to whether they had read the article, the court addressed the jury as a whole as follows: "[I]f any juror violated the in-
} 
cusing a juror would be the same as on voir dire except that a juror would be excused if he had heard or seen potentially prejudicial material which if referred to in the trial would constitute grounds for mistrial. ${ }^{153}$

The Standards suggest as a further method for impaneling an impartial jury that the trial court have authority to draw jurors from other localities. ${ }^{154}$ This should be done whenever potentially prejudicial news coverage has been intense and relatively localized. Here, of course, the outside veniremen would be alerted to the exceptional nature of the proceeding, and they might resent the inconvenience of being called to another district for what may promise to be a protracted trial. ${ }^{155}$

\section{Waiver of Jury Trial}

The Standards recommend that in jurisdictions where there is at present no absolute right to waive a jury trial, ${ }^{156}$ permission for

structions of the court and read the article ... hold up your hand." 236 F.2d at 269-70.

153 STANDARDS $\$ 3.5(\mathrm{f})$.

106 Id. $\$ 3.4$ (c). See Graham v. United States, 257 F.2d 724, 728-29 (6th Cir. 1958). See generally Note, 60 Colum. L. REv. 349, 365-67 (1960).

${ }^{165}$ The danger of transferred resentment has been mentioned as an important tactical consideration for defense counsel. See Sheppard v. Maxwell, 346 F.2d 707, 713 n.3 (6th Cir. 1965), rev'd, 384 U.S. 333 (1966); Meyer, supra note 135, at 17; Note, 60 Colum. L. REv. 349, 365-67 (1960).

${ }_{100}$ Generally the right to waive a jury trial by one who is charged with the commission of a felony in a state court is not recognized in the absence of statutory authority. E.g., Morgan v. People, 136 Ill. 161, 26 N.E. 651 (1891); State v. Stricker, 196 Iowa 290, 194 N.W. 60 (1923); State v. Williams, 195 Iowa 374, 191 N.W. 790 (1923). Contra, Marino v. State, 111 Neb. 623, 197 N.W. 396 (1924). Statutes permitting waiver where the accused is charged with a felony, however, have been upheld. E.g., Hallinger v. Davis, 146 U.S. 314 (1892); Batchelor v. State, 189 Ind. 69, 129 N.E. 773 (1920); People v. Sanford, 252 Mich. 240, 233 N.W. 192 (1930); State v. Furstenau, 167 Neb. 439, 93 N.W.2d 384 (1958). States have adopted a variety of procedures by which waiver of jury trials is permitted. Most require the permission of the trial judge or prosecutor. See Singer v. United States, 380 U.S. 24, 36-37 (1965) (lists many of the methods states now provide). When the trial arises from a misdemeanor or petty offense, the defendant may waive his right with or without statute. E.g., Schich v. United States, 195 U.S. 65 (1904); Redd v. State, 169 Ala. 6, 53 So. 908 (1910); State v. Shearer, 27 Ariz. 311, 232 Pac. 893 (1925); State v. Ross, 47 S.D. 188, 197 N.W. 234 (1924); Osborn v. State, 143 Wis. 249, 126 N.W. 737 (1910). See generally Oppenheim, Waiver of Trial by Jury in Criminal Cases, 25 MrCH. L. REv. 695 (1927).

The accused is permitted to waive his right to a jury trial in the federal courts only with the approval of the government counsel and the trial judge. Patton v. United States, 281 U.S. 276, 312 (1929). See generally Goldberg, Waiver of Jury in Felony Trials, 28 Mich. L. REv. 163 (1929). See Singer v. United States, supra, where the Court denied the defendant's contention that he had an unconditional constitutional 
waiver be given a defendant when it is determined that the waiver is voluntary and is necessary to increase the likelihood of a fair trial. ${ }^{157}$ Here again is the problem of relinquishing one right to obtain another. ${ }^{158}$ In addition, in at least one state the jury trial is a constitutional requirement, ${ }^{150}$ making this protection a possible millstone in notorious cases. ${ }^{160}$ One commentator has concluded that waiver of jury trial is the only solution to the prejudicial extraneous influence problem. ${ }^{161}$ While our trial judiciary may certainly be expected to be more resolute and less susceptible to influence by prejudicial extraneous matter ${ }^{162}$ than jurors, several authorities have questioned their complete immunity from such influences. ${ }^{163}$

\section{Control of Courtroom}

Assuming that an impartial jury has been impaneled, the jurors must be sufficiently insulated to retain their impartiality. Recalling Sheppard v. Maxwell ${ }^{164}$ and Estes v. Texas, ${ }^{165}$ as well as criticism directed at several notable earlier trials, ${ }^{108}$ the Standards urge the trial judge to maintain decorum at all times and to supervise closely those in attendance. ${ }^{167}$

right to waive a trial by jury in the federal courts. See generally Orfield, Trial by Jury in Federal Criminal Procedure, 1962 Duke L.J. 29.

167 STANDARDS \$ 3.3 .

${ }^{188}$ See Meyer, supra note 135, at 18.

${ }^{180}$ N.C. Const. art. IV, § 12.

${ }^{100}$ See Singer v. United States, 380 U.S. 24, 37 (1965); United States v. Kobli, 172 F.2d 919 (3d Cir. 1949).

${ }^{102}$ Note, 11 N.Y.L.F. 533, 546 (1965).

103 "Judges are supposed to be men of fortitude, able to thrive in a hardy climate." Craig v. Harney, 331 U.S. 367, 376 (1947).

108 See id. at 391-92 (Frankfurter, J., dissenting); (judges appointed for good be. bavior more resolute than a local judge elected for a short term); id. at 395-97 (Jackson, J., dissenting) (same); Pennekamp v. Florida, 328 U.S. 331, 357 (1946) (Frankfurter, J., concurring).

104384 U.S. 333 (1966).

108381 U.S. 532 (1965).

200 See Sulivan, Trial by Newspaper (1961); Hallam, Some Object Lessons on Publicity in Criminal Trials, 24 MINN. L. Rev. 453 (1940); Isaacs, The Crime of Crime Reporting, 7 CrIME \& DELIN. 312 (1961).

${ }^{107}$ STANDARDS $\$ 3.5$ (a). This recommendation is not limited to disturbances attributable to the press, but would also encompass disruptive and extraneous influences from other sources. Compare notes 86-88, 90 supra and accompanying text. The trial judge himself may exert undue influence on jurors. See note 204 infra and accompanying text. Spectator conduct may also be influential, see Hallam, supra note 166 , at $456-60,480-84$, and some incidents may be so prejudicial that no instruction will cure them, see Beck v. Wings Field, Inc., 122 F.2d 114, 116 (3d Cir. 1941). 


\section{Sequestration}

Sequestration, often criticized for its cost and inconvenience, ${ }^{108}$ is encouraged by the Standards. Sequestration is to be ordered on motion by either party or the court sua sponte on a showing that otherwise highly prejudicial matters are likely to reach the jury. Furthermore, the judge would be forbidden to disclose the requesting party to the jury. ${ }^{100}$ The jurors' reaction to being inconvenienced ${ }^{170}$ could be migtiated by explaining that sequestration is necessary to keep possibly erroneous information from coming to their attention and to ensure fairness to the accused and the prosecution.

\section{Instructions}

Instructions to jurors have long been the subject of tension between faith in the efficacy of the jury system and recognition of the dangers of prejudicial publicity. ${ }^{171}$ While Mr. Justice Jackson's statement demeaning limiting instructions as sheer fiction is legendary, ${ }^{172}$ it is suggested that Judge Frank more accurately expressed the skeptic's doubts when he said that telling a juror to disregard something is like telling a small boy to stand in a corner and not to think of a white elephant. ${ }^{173}$ These views notwithstanding, the Standards would have trial judges tell jurors early and often to avoid extrajudicial sources of information and influence. ${ }^{174}$

${ }^{108}$ See Meyer, note 185 supra, at 17-18; Comment, 51 Cornell L.Q. 306, 316 (1966). 109 STANDARDS $\$ 3.5$ (c).

${ }^{170}$ See Sheppard v. Maxwell, 346 F.2d 707, 713 n.3 (1965), rev'd, 384 U.S. 333 (1966); Meyer, supra note 135 , at 17-18.

${ }^{171}$ See Smith v. United States, 236 F.2d 260, 269-70 (8th Cir.), cert. denied, 352 U.S. 909 (1956); Beck v. Wings Field Inc., 122 F.2d 114, 116 (3d Cir. 1941) (material so prejudicial no instruction could cure). See generally FrANK, LAW AND THE MODERN MIND 170.85, 302-09 (1932). But see United States v. Howell, 240 F.2d 149, 158 (3d Cir. 1956).

172 "The naive assumption that prejudicial effects can be overcome by instructions to the jury ... all practicing lawyers know to be unmitigated fiction." Krulewitch v. United States, 336 U.S. 440, 453 (1949) (Jackson, J., concurring).

${ }^{173}$ United States v. Leviton, 193 F.2d 848, 865 (2d Cir. 1951) (dissenting opinion), cert. denied, 343 U.S. 946 (1952).

${ }^{274}$ STANDARDS $\S 3.5(e)$. Furthermore, the judge should give cautionary: instructions in a manner such as not to make jurors curious to read what they have been warned against. For example in Centoni v. United States, 69 F.2d 624, 625 (9th Cir. 1934), "the [trial] Court inquired of the jury present if any of the jurors had read the article, to which inquiry four of the jurors answered in the affirmative. Thereupon the Court directed that they be not called as jurors in the case, and that all of the members of the jury refrain from reading the article appearing on page three of the Tacoma Times of June 13th, giving them the number of the article and the page upon which it appeared." 


\section{Setting Aside the Verdict}

Finally, the Standards recommend that a verdict of guilty be set aside and a new trial ordered whenever the court finds on the basis of competent evidence a substantial likelihood that the vote of one or more jurors had been influenced by exposure to an extrajudicial communication relating to the defendant or the case which was not part of the trial record. ${ }^{175}$ Competent evidence would undoubtedly include circumstantial evidence or testimony of one who was not himself a juror. However, the Standards' recommendation expressly disclaims any intention to affect the generally prevailing rule against permitting jurors to impeach their own verdicts. ${ }^{170}$ In jurisdictions in which this prohibition is in effect, the Standards' recommendation would be less effective in discovering the impact of prejudicial extraneous influences on jurors than it would be in the minority of jurisdictions which permit jurors to testify to the existence, although not to the effect, of extraneous influences. ${ }^{177}$

\section{Summary}

The remedies available at trial, as strengthened and expanded by the Standards, would increase the likelihood of a fair decision. Indeed, given an impartial panel, these safeguards seem adequate to insulate the jury until verdict. However, since no chain is stronger than its weakest link, it is arguable that the degree of impartiality attained can be no greater than that of the jury impaneled after voir dire and challenges. ${ }^{178}$ Because the chorus condemning the effectiveness of these impaneling procedures in notorious cases is growing as empirical data is gathered, ${ }^{179}$ the protection afforded by the trial level remedies in such cases would seem to be inadequate.

\footnotetext{
${ }^{278}$ STANDARDS $\$ 3.6$.

270 Ibid.

${ }^{177}$ Sce Mattox v. United States, 146 U.S. 140 (1892). Sce generally Comment, 25 U. ChI. L. Rev. 360 (1958).

${ }^{178}$ Irvin v. Dowd, 366 U.S. 717, 729 (1961) (Frankfurter, J., concurring); see Com. ment, 33 U. CHI. L. REV. 512, 514 (1966).

${ }_{270}$ Broeder, Voir Dire Examination: An Empirical Study, 38 So. GAx. L. Rev. 503, 528 (1965); Goldfarb, Public Information, Criminal Trials and the Cause Celebre, 36 N.Y.U.L. REv. 810, 821-22 (1961); Jaffce, The Press and the Oppressed-Part I, 56 J. CrTM. L., C. \& P.S. 1, 17 (1965); Will, Free Press us. Fair Trial, 12 DePaUl L. Rev. 197, 209-11 (1963); Note, 60 Colum. L. Rev. 349, 377 (1960); Comment, 51 CornelL L.Q. 306, 313 (1966); Comment, 57 Nw. L.L. REv. 217, 235 (1962).
} 


\section{ANTIDISSEMINATION}

In addition to the proposed methods of control based on posttrial and trial level remedies, courts, legislators, and commentators have advocated restrictions on the extrajudicial dissemination of potentially prejudicial material. ${ }^{180}$ The antidissemination proposals vary with respect to the subject matter, ${ }^{181}$ timing, ${ }^{182}$ and imple-

${ }^{180}$ Sheppard v. Maxwell, 384 U.S. 333, 361 (1966); State v. Van Duyne, 43 N.J. 369, 389, 204 A.2d 841, 852 (1964), cert. denied, 380 U.S. 987 (1965); Dep't of Justice Release Relating to Criminal Proceedings, 28 C.F.R. \$50.2 (1965); S. 290, 89th Cong., lst Sess. (1965) (reproduced and evaluated in Comment, 33 U. CHr. L. Rev. 512, 51819 (1966)); Mass. H.B. 3991 (1965) (reproduced and evaluated in Comment, 33 U. Crr. L. Rev. 512, 519-22 (1966)). See InbaU \& Sowle, Cases on Criminal Justice 1093-96 (2d ed. 1964); Jaffee, The Press and the Oppressed-Part II, 56 J. CRIM. L., C. \& P.S. 158, 166-69 (1965); Jaffee, Trial by Newspaper, 40 N.Y.U.L. REv. 504, 523-24 (1965); Will, supra note 179, at 214-16; Note, 60 ColuM. L. REv. 349, 370-75 (1960); Note, 54 Kx. L.J. 141, 150-54 (1965); Comment, 57 Nw. U.L. REv. 217, 250-54 (1962); Comment, 33 U. Chr. L. Rev. 512, 523-30 (1966). But see Goldfarb, supra note 179, at 835-38; Jaffee, Trial by Newspaper, 40 N.Y.U.L. REv. 504, 519 (1965); Wright, Fair TrialFree Press, 38 F.R.D. 435, 436-37 (1965).

At one extreme are those who feel that prejudicial extraneous influences are becoming more prevalent and that action is therefore required (beyond reversals) to secure to the accused a trial free of these outside influences. See Sheppard v. Maxwell, supra at 362; State v. Van Duyne, supra at 388, 204 A.2d at 851; Note, 54 KY. L.J. 141 (1965); Comment, 57 Nw. U.L. REv. 217 (1962). In the intermediate position are those who recommend the use of voluntary or indirect restraints before application of antidissemination controls. See Will, supra note 179, at 211-14; Comment, $33 \mathrm{U}$. CHr. L. REv. 512, 523-30 (1966). Finally, there are those who recommend other solutions to the problem. See Comment, 51 Cornelc L.Q. 306, 325-27 (1966) (jury selection); Note, 11 N.Y.L.F. 533, 546 (1965) (waive jury trial).

On the other hand, the opponents of nondisclosure contend that there is no need for restrictions on dissemination since the number of cases involving prejudicial extraneous influences is small and that any advantages derived from such restrictions are far outweighed by the benefits of an unshackled press. See Daniel, Fair Trial and Freedom of the Press, Case \& Com., Sept.Oct. 1966, p. 3, at 6; Wright, supra at 435-37.

${ }^{281}$ The following types of information are deemed prejudicial by the authorities indicated. (1) Confessions: State v. Van Duyne, 43 N.J. 369, 380, 204 A.2d 841, 852 (1964), cert. denied, 380 U.S. 987 (1965); Jaffee, The Press and the Oppressed-Part I, 56 J. CRIM. L., C. \& P.S. I, 5 (1965); Jaffee, Trial by Newspaper, 40 N.Y.U.L. REv. 504, 524 (1965); Will, supra note 179, at 215; Comment, 5 I CoRnel. L.Q. 306, 323 (1966); Comment, 57 Nw. U.L. REv. 217, 252 (1962). (2) Prior criminal activities: State v. Van Duyne, supra at 389, 204 A.2d at 852; Jaffee, The Press and the Oppressed-Part I, 56 J. CRIM. L., C. \& P.S. 1, 6 (1965); Jaffee, Trial by Newspaper, 40 N.Y.U.L. REv. 504, 524 (1965); Will, supra note 179, at 215; Comment, 5 I CORNELL L.Q. 306, 323 (1966); Note, 54 KY. L.J. 141, 152 (1965); Comment, 57 Nw. U.L. REv. 217, 252 (1962). (3) Illegally seized incriminating evidence: Jaffee, The Press and the Oppressed-Part I, 56 J. CRIM. L., C. \& P.S. 1, 6-7 (1965); Will, supra note I79, at 215; Note, 54 KY. L.J. 141, 152 (1965); Comment, 57 Nw. U.L. REv. 217, 252 (1962). (4) Statements of persons who may not actually testify: Sheppard v. Maxwell, 384 U.S. 333, 361 (1966); Jaffee, The Press and the Oppressed-Part I, 56 J. CRn. L., C. \& P.S. 1, 6 (1965); Note, 54 KY. L.J. 141, 152 (1965); Comment, 57 Nw. U.L. REv. 217, 252 (1962). (5) Reports of proceedings from which the jury has been excluded: Jaffee, The Press and the 
mentation of the restrictions. ${ }^{183}$ Each of these factors will be considered with reference to the treatment given them by the Standards and by the relevant case law and commentary.

\section{Subject Matter}

The Standards list six categories of restricted material, the dissemination of which would be controlled, including information that relates to the prior criminal record or character of the defendant; the existence or contents of any confession given by the defendant; the performance of any tests or the refusal of the defendant to submit thereto; the identity, testimony, or credibility of prospective witnesses; the possibility of a plea of guilty; and the defendant's guilt or innocence..$^{184}$

Oppressed-Part I, 56 J. Crum. L., C. \& P.S. 1, 7 (1965); Note, 54 KY. L.J. 141, 152 (1965); Comment, 57 Nw. U.L. REv. 217, 252 (1962). (6) Refusal to submit to lie detector test: Sheppard v. Maxwell, supra at 361; Will, supra note 179, at 215. (7) Information bearing on guilt or innocence: Sheppard v. Maxwell, supra at 361; Jaffee, Trial by Newspaper, 40 N.Y.U.L. Rev 504, 524 (1965); Comment, 51 CorNels L.Q. 306, 323 (1966). (8) Statements concerning the merits of the case: Sheppard v. Maxwell, supra at 361; State v. Van Duyne, supra at 389, 204 A.2d at 852.

${ }^{182}$ See notes 217-19 infra and accompanying text.

${ }^{283}$ Compare Will, supra note 179, at 211-14 with Comment, 57 Nw. U.L. REv. 217, 251-54 (1962).

${ }_{184}$ STANDARDS $\$ 1.1$ recommends that the Canons of Professional Ethics be revised to prohibit disclosures by lawyers concerning the accused's prior criminal record, performance of or refusal to submit to any tests or examinations, identity or testimony of prospective witnesses, possibility of a plea of guilty to a lesser offense, and statements concerning the merits of the case.

STANDARDS $\$ 2.1$ recommends that law enforcement officers subject to the jurisdiction of the court not make any extrajudicial statements relating to the same six areas enumerated in $\$ 1.1$.

STANDARDS $\$ 2.3$ would prohibit "any judicial employee from disclosing, to any unauthorized person, information relating to a pending criminal case that is not part of the public records of the court and that may tend to interfere with the right of the people or of the defendant to a fair trial."

STANDARDS $\$ 3.5$ (c) provides that "whenever appropriate in light of the issues in the case or the notoriety of the case, the court shall instrnct parties and witnesses not to make extrajudicial statements, relating to the case or the issues in the case, for dissemination by any means of public communication during the course of the trial."

STANDARDS $\$ 3.5$ (d) states that "if the jury is not sequestered, the defendant shall be permitted to move that the public be excluded from any portion of the trial that takes place outside the presence of the jury on the ground that dissemination of evidence or argument adduced at the hearing is likely to interfere with the defendant's right to a fair trial by an impartial jury."

STANDARDS $\$ 4.1$ relates to the general public; it prohibits certain disclosures and provides sanctions "against a person who, knowing that a criminal trial by jury is in progress or that a jury is being selected for such a trial: (i) disseminates by any means of public communication or extrajudicial statement relating to the defendant or to the issues in the case that goes beyond the public record of the court in the 
Because of the state of the law concerning extrajudicial confessions, it is never certain that the defendant's incriminating disclosures will be admissible until his statement is received in court. ${ }^{\mathbf{1 8 5}}$ Moreover, nothing is so damning as an admission from the accused's own lips, even if it is later deemed incompetent. ${ }^{186}$ The Standards would preclude out-of-court dissemination of material concerning any confession, admission, or statement made by the defendant. ${ }^{187}$ To curb the manifest potential for prejudice arising from the disclosure of a possible negotiated plea of guilty, the Standards would prohibit dissemination of material relating to the entry of a guilty plea to the offense charged or to a lesser offense. ${ }^{188}$

In view of the evidentiary limitations imposed upon the introduction of the defendant's prior criminal record or evidence of his bad character, ${ }^{189}$ the Standards' position with regard to this type of information is eminently sound. ${ }^{190}$ In striking contrast are the

case, if the statement is reasonably calculated to affect the outcome of the trial and seriously threatens to have such an effect; or (ii) makes such a statement with the expectation that it will be so disseminated."

${ }^{185}$ See notes 29.32 supra and accompanying text.

${ }^{180}$ See letter from New York County District Attorney Hogan, 131 N.X.L.J., April 22, 1954 , p. 4, cols. $3-4$, in which he defends his policy of declining to disclose the contents of statements made by prospective criminal defendants, or to label such statements as confessions: "It seems undeniable that widely disseminated information that a defendant has 'confessed' has the effect of convincing the general public that he is unquestionably guilty and that any trial will be a mere formality. To obtain an impartial jury under such circumstances, therefore, may be a most difficult task. In its practical effect, such publication tends to destroy the presumption that an accused is innocent until he is proven guilty beyond a reasonable doubt in a court of law.

"The vice inherent in the situation stands out in bolder relief where the statement is never even received in evidence. Such a statement sometimes is excluded as not being a confession at all by a court ruling that duress preceded or accompanied it; or that it was given under some inducement of promise of benefit; or that it resulted from some unfair psychological pressure; or that the person was in such an unstable mental condition at the time as to preclude credence of any statement made by him. For these or similar reasons indeed, the prosecutor himself may decide not to offer the statement in evidence at the trial."

${ }^{187}$ Standaras $\$ 1.1$ (2). See Shepherd v. Florida, 341 U.S. 50, 51 (1951) (Jackson, J., concurring), where a confession was published but never admitted into evidence. In People v. Brommel, 56 Cal. 2d 629, 636, 15 Cal. Rptr. 909, 913, 364 P.2d 845, 849 (1961), the prosecutor released the accused's confession to the press; it was admitted into evidence but the admission was held to have been erroneous.

${ }^{183}$ STANDARDS $\$ 1.1$ (5) (disclosure by lawyers); $\$ 2.1$ (5) (disclosure by law enforcement officers). Possibly $\$ 4.1$ (a) (i) (note 184 supra) might include guilty pleas with the result that the news media would be hable for contempt. See Griffin v. United States, 295 Fed. 437 (3d Cir. 1924).

${ }^{180}$ See notes 50.51 supra and accompanying text.

${ }^{100}$ STANDARDS $\$ 1.1(1)$ (disclosure by lawyers); $\$ 2.1$ (1) (disclosure by law enforcement officers). Possibly $\$ 4.1$ (a) (i) (note 184 supra) might include the accused's prior record with the result that the news media would be liable for contempt. 
Attorney General's Rules, which authorize the release of federal convictions upon request. ${ }^{191}$ The justification advanced for this practice is the public need to know about the success of the federal penal system, its courts, prisons, parole boards, and about the extent of recidivism. ${ }^{192}$ Similar reasons are advanced by critics of a prohibition on the dissemination of prior criminal records, ${ }^{103}$ although they fail to state why such information must be made available before trial, rather than contemporaneously with its introduction into evidence or after conclusion of the trial.

Another category of restricted material includes tests, their results, or the accused's refusal to submit to them. ${ }^{104}$ It has been suggested that such information may have greater impact through pre-trial disclosure than if it were brought out at trial where efforts could be made to discredit its reliability or explain the accused's position in not taking the test. ${ }^{195}$ A similar justification exists for prohibiting the dissemination of witnesses' statements. ${ }^{108}$ In the Supreme Court's Sheppard opinion there are references to "bombshell" witnesses never produced ${ }^{107}$ and testimony never adduced at trial. ${ }^{108}$ There have been examples of witnesses so influenced by pre-trial exposure that their testimony was later shown to have been the result of suggestion and completely untrue. ${ }^{102}$ While it may be argued that disclosure will expose a changed story or fraud, 200 it likewise may discourage an alteration of position based on recoguition of an earlier mistake.

${ }^{101}$ See Dep't of Justice Release Relating to Criminal Proceedings, 28 C.F.R. $\S 50.2$ (b) (4) (1965).

102 Ibid.

${ }^{103}$ See, e.g., Daniel, Fair Trial and Freedom of the Press, Case \& Com., Sept.-Oct. 1966, P. 3; Wiggins, The Press and Conflicts of Interest, 24 FED. B.J. 358, 360 (1964); Wright, Fair Trial-Free Press, 38 F.R.D. 435 (1965).

204 STANDARDS $\$ \$ 1.1$ (3), 2.1 (3).

105 See Sheppard v. Maxwell, 384 U.S. 333, 361 \& n.15 (1966); United States ex rel. Bloeth v. Denno, 313 F.2d 364, $372-73$ (2d Cir.), cert. denied, 372 U.S. 978 (1963); Will, supra note 179, at 215; Comment, 38 So. CAL. L. REv. 672, 676-83 (1965).

${ }^{208}$ STANDARDS $\$ 1.1$ (4) (disclosure by lawyers); $\$ 2.1$ (4) (disclosure by law enforcement officers). Possibly $\S 4.1$ (a) (i) (note 184 supra) might include witnesses' statements with the result that the news media could be cited for contempt.

${ }^{107}$ Sheppard v. Maxwell, 384 U.S. 333, 348 (1966).

${ }^{108} \mathrm{Id}$. at $360-61$.

109 In one famous case the victim of a crime read a report that the fingerprints of the accused were those of the culprit and she then identified the accused. He was convicted on the basis of this identification even though no fingerprint evidence was ever introduced in evidence. Fortunately, the defendant was later exonerated. BORCHARD, CONVICTING THE INNOCENT 194-200 (1932).

${ }^{200}$ See Wiggins, The Public's Right to Public Trial, 19 F.R.D. 25, $27-28$ (1955). 
A most serious aspect of pre-trial disclosure, often described as "trial by newspaper" but not limited to that particular medium, ${ }^{201}$ is the pre-trial verdict or expression of guilt. Some commentators have stated that such statements by police and prosecutors are discounted by the public, ${ }^{202}$ but others suggest that the amount of credence derives from the official nature of the source. ${ }^{203}$ Under this latter view, opinions of the judiciary are the most harmful, ${ }^{204}$ followed by those of government officials such as legislators, ${ }^{205}$ prosecutors, ${ }^{208}$ and police. ${ }^{207}$

The Standards also list material which is excepted from the class of restricted information. ${ }^{208}$ Circumstances of arrest, including time, place, resistance, pursuit, and the use of weapons, and descriptions of the investigation and the evidence seized may be released for dissemination..$^{209}$ However, these may in fact be unwarranted and undesirable exceptions. There does not appear to be a sound distinction between the public's need to know about prior crimes and its need for information concerning resistance at arrest; both disclosures tend to show the general bad character of the accused. Moreover, as is the case with a prior criminal record, evidence of flight to avoid capture may be admissible, but only under limiting instructions. ${ }^{210}$ In addition, the possibility for prejudice arising from the disclosure of seized evidence may be as great as that arising

201 "We use the term 'trial by newspaper' as a shorthand for the variety of means whereby all sorts of information germane to a criminal case is published prior to or pending the trial." Jaffee, Trial by Newspaper, 40 N.Y.U.L. REv. 504 (1965).

202 See id. at 519; Wright, supra note 193, at 436-37.

${ }^{203}$ See Sheppard v. Maxwell, 384 U.S. 333, 361 (1966); State v. Van Duyne, 43 N.J. 369, 389, 204 A.2d 841, 852 (1964), cert. denied, 380 U.S. 987 (1965).

204 See Quercia v. United States, 289 U.S. 466, 468-72 (1933); Burroughs v. United States, 365 F.2d 431, 433-34 (10th Cir. 1966); Briggs v. United States, 221 F.2d 636, 639 (6th Cir. 1955); Henry v. United States, 204 F.2d 817, 821 (6th Cir. 1953); United States v. Powell, 171 F. Supp. 202, 205 (N.D. Cal. 1959).

${ }^{205}$ See Delaney v. United States, 199 F.2d 107, 114-15 (1st Cir. 1952); United States v. Florio, 13 F.R.D. 296, 299 (S.D.N.Y. 1952) (motion for change of venue granted where much of adverse publicity appearing in the press had its origin in the investigation of the New York State Crime Commission).

${ }^{200}$ Stroble v. California, 343 U.S. 181, $197-98$ (1952); United States v. Nilanovich, 303 F.2d 626, 629-30 (4th Cir.), cert. denied, 371 U.S. 876 (1962); Fouquette v. Bernard, 198 F.2d 96, 98-100 (9th Cir. 1952), cert. denied, 345 U.S. 912 (1953).

${ }^{307}$ Shepherd v. Florida, 341 U.S. 50, 51 (1951) (Jackson, J., concurring), where it was published that the defendants had confessed and the statement was attributed to the sheriff. No confession was ever introduced at the trial.

${ }^{208}$ STANDARDS $\$ \S 1.1(6), 2.1(6)$.

200 Ibid.

${ }^{210}$ See Burroughs v. United States, 365 F.2d 431, 432-33 (10th Cir. 1966). 
from the disclosure of extrajudicial confessions, for the ultimate admissibility of such evidence is equally uncertain. ${ }^{211}$

An additional category of material exempted from restriction by the Standards consists of information needed to aid in the capture of a suspect and to warn the public of his dangerous traits.212 Although this exception is apparently based on greater public necessity than those dealing with circumstances of arrest, even in this context restraint may be in order so that the emphasis is placed on information rather than sensationalism..$^{213}$

Under the Standards' recommendations the only matter publishable during the trial would be the public record of the proceedings, devoid of comment. On motion by or with the consent of the accused, the public might be excluded from hearings out of the jury's presence when the argument or evidence is such that its dissemination might prejudice the accused. A complete record of such a hearing would be kept and made available to the public after trial. In addition, the judge would have the power to control the dissemination of matter by those permitted to remain when the jury is absent.214 Post-verdict statements would be proscribed to the extent that they might influence any further proceedings. ${ }^{215}$

\section{Timing}

The effectiveness of any limitations on disclosure will depend largely upon when they become controlling. The Standards suggest

212 Neither the federal government nor the states may convict a defendant by means of evidence obtained in violation of the constitutional prohibition against illegal search and seizure. Mapp v. Ohio, 367 U.S. 643 (1961). Obviously, if publicity makes the jury aware that inadmissible evidence implicating the defendant has been obtained, his constitutional right not to be convicted on the basis of illegally seized evidence is irreparably damaged. For example, in United States v. Kum Seng Seo, 300 F.2d 623 (3d Cir. 1962), the defendant was indicted for receiving and concealing heroin. The defense constructed its case on the theory that the heroin belonged to the defendant's daughter. During the course of the trial a newspaper article appeared, which the jurors read, stating that the heroin had been found in defendant's room. Tlie story was completely untrue. The case was reversed under Marshall, but it is mentioned here as an illustration of the problem.

Most proposals recognize the possibility for prejudice arising from the disclosure of information relating to illegally seized evidence. See, e.g., Note, 54 K.. L.J. 141, 152 (1965); Comment, 57 Niv. U.L. REv. 217, 252 (1962).

212 STANDARDS $\$ 2.2(2)$.

${ }^{213}$ See Juelich v. United States, 214 F.2d 950 (5th Cir. 1954).

214 STANDARDS $\$ 3.5$ (d).

${ }^{215}$ Id. $\$ 1.1$ (statements by lawyers). It is significant to note that the restriction on post-verdict pronouncements is not applied to law enforcement officials by the STANDARDS. Id. $\$ 2.1$. 
strong enforcement provisions from the time of formal arrest, indictment, or information. ${ }^{216}$ In addition, law enforcement agencies are urged to limit their own releases through departmental regulations. Such regulations would conform to the spirit of the Standards restrictions in precluding anything unnecessarily prejudicial to the accused and by taking effect as soon as the commission of a crime is suspected. ${ }^{217}$ On the other hand, antidissemination remedies which have been proposed by courts and commentators take effect later in time, either at indictment $t^{218}$ or at the initiation of voir dire examination. ${ }^{219}$ These proposals seem to assume the effectiveness of voir dire or the inability to enforce restrictions on disclosure before a court assumes jurisdiction of the case. ${ }^{220}$ Restrictions on dissemination during the trial have been imposed where pre-trial publicity had been highly inflammatory, ${ }^{221}$ but such restrictions have also been successfully challenged as unconstitutional abridgments of first amendment freedoms. ${ }^{222}$ The Standards' antidissemination provisions would be effective until the potentially prejudicial material had become part of the public record or could no longer influence a jury. ${ }^{223}$ Sequestration of the jury or waiver of jury trial would obviate the necessity of these provisions.

Beginning the restrictions on disclosure at the time of arrest, rather than at some later time, would seem preferable in terms of prevention of prejudice to the accused, although more stringent enforcement procedures might be desirable to limit pre-arrest disclosure by police. The Standards would subject the press to sanctions for dissemination only when a jury trial is in progress or during

${ }^{216} I d$. $\$ 1.1$ (statements by lawyers); id. $\$ 2.1$ (statements by law enforcement officials). The press, however, is liable to a contempt citation only when a "criminal trial by jury is in progress ... or [when] . . a jury is being selected for such a trial ...."Id. $\$ 4.1$ (a).

${ }^{217}$ See id. $\$ 2.2$. Other recent proposals have advocated that no dissemination of information should be permitted by any person after the commission of the alleged crime. See Jaffee, The Press and the Oppressed-Part 1I, 56 J. CRIM. L., C. \&. P.S. 158, 167 (1965); Note, 54 KY. L.J. 141, 151 (1965); Comment, 57 Nw. U.L. REv. 217, 251 (1962).

${ }^{218}$ Sheppard v. Maxwell, 384 U.S. 333, 361 (1966).

${ }^{210}$ Jaffee, Trial by Newspaper, 40 N.Y.U.L. REv. 504, 524 (1965).

220 See id. at 521-22; Special Comm. on Radio, Television and the Administration of Justice of the N.Y.C.B.A., Report. See N.Y. Times, Feb. 24, 1967, p. 18, cols. 1-5 (city ed).

${ }_{221}$ McDonald v. United States, 282 F.2d 737, 741-42 (9th Cir. 1960).

${ }_{222}$ See Phoenix Newspapers, Inc. v. Superior Court, 101 Ariz. 257, 418 P.2d 594 (1966); Wall Street Journal, March 7, 1967, p. 18, col. 3.

${ }^{223}$ See STANDards $\$ \$ 1.1,2.1$. 
the process of jury selection. ${ }^{24}$ This approach would leave immune the type of pre-trial editorial attacks on police which occurred in the Sheppard case. ${ }^{225}$ Furthermore, the provision for removing restrictions when material becomes a matter of public record at the trial ${ }^{220}$ would allow for accurate and timely coverage of trials in progress, negating the suggestion ${ }^{227}$ that these restrictions would produce a return to Star Chamber procedures.

\section{Implementation}

The truly controversial proposals of the Standards are those dealing with the designation of those upon whom disclosure restrictions should be placed and with the suggestion of methods to produce compliance or sanction noncompliance. ${ }^{228}$ Here are raised the familiar cries of censorship, press muzzling, and police state tactics. ${ }^{220}$ While certain of the restrictions meet general approval, ${ }^{230}$ the concept of enforced nondisclosure on a wide scale foments heated discussion. 231

Little controversy arises from the proposals which would restrict

s26 Id. §4.1 (a).

${ }^{238}$ See Sheppard v. Maxwell, 231 F. Supp. 37, 44-60 (S.D. Ohio 1964), rev'd, 946 F.2d 707 (6th Cir. 1965), rev'd, $\$ 84$ U.S. 339,861 (1966). Restrictions upon dissemination by the press only when a trial is in progress would also permit pretrial editorial attacks on the accused.

${ }^{230}$ STANDARDS $\S 1.1$ (statements by lawyers); $i d . \S 2.3$ (statements by judicial employees); id. $\S 4.1$ (a) (i) (statements by any person).

237 See Daniel, supra note 193, at 6; Wiggins, The Public's Right to Public Trial, 19 F.R.D. 25, 26 (1955); Wright, supra note 193, at 435-36.

${ }^{228}$ STANDARDS $\$ 4.1$ (a) recommends limited use of the contempt power against auy person who "disseminates by any means of public communication an extrajudicial statement relating to the defendant or to the issues in the case that goes beyond the public record of the court in the case, if the statement is reasonably calculated to affect the outcome of the trial and seriously threatens to have such an effect ...." In addition to encountering opposition from the news media, this suggestion has been criticized by the individual-oriented American Civil Liberties Union. N.Y. Times, Dec. 8, 1966, p. 54, col. 4 (city ed.).

${ }^{220}$ Daniel, supra note 193 , at 6 .

${ }^{230}$ The American Civil Liberties Union did not object to restrictions upon attorneys and law enforcement officials. N.Y. Times, Dcc. 8, 1966, p. 54, col. 4 (city ed.). In addition, many advocates of tbe news media position have maintained that enforcement of Canon 20 (see note 232 infra) and the silencing of the police are desirable. "What matters most is not what newspapers say but what lawyers and judges do. The press, for the most part, merely holds up a mirror to these actions." Daniel, stupra note 193, at 4. See Wiggins, The Press and Conflicts of Interest, 24 FED. B.J. 358, 361 (1964); Wright, supra note 193, at 438.

${ }_{281}$ See Speclal Comm, on free Press and fair Trial of the Amfrican Newspaper PUblishers Ass'N, Report: Fref. Press and liair Trial 1-10 (1967); Daniel, supra note 193, at 6 . 
statements by attorneys for both prosecution and defense. Such a restriction is not markedly different from canon $20,{ }^{232}$ which now supposedly governs the actions of attorneys. Many critics of broad compulsory restrictions point with scorn to the ineffectiveness of canon $20,{ }^{233}$ while members of the legal profession attribute the impotence of canon 20 to a lack of effective enforcement. ${ }^{234}$ The Standards suggest that restrictive measures be enforced by both bar associations and the bench, with the contempt power ultimately available. $^{235}$ In the latter connection, it has been suggested that the status of attorneys as officers of the court will allow punishment by contempt proceedings. ${ }^{236}$ However, the Supreme Court opinion in In re Sawyer ${ }^{237}$ may cast doubt upon this assumption. In that case the suspension from practice of an attorney for constructive contempt was vacated.238 The decision ostensibly turned on a question of proof, ${ }^{239}$ but there are intimations in the opinion that the strict "clear and present danger" approach used in the more recent contempt by publication cases ${ }^{240}$ will be applied. ${ }^{241}$ If so strict a standard were imposed, the effectiveness of contempt as a sanction for wrongful disclosure would be severely limited. ${ }^{242}$

232 A.B.A. Canon of Professional Ethics 20: "Newspaper publications by a lawyer as to pending or anticipated litigation may interfere with a fair trial in the Courts and otherwise prejudice the due administration of justice. Generally they are to be condemned. If the extreme circumstances of a particular case justify a statement to the public, it is unprofessional to make it anonymously. An ex parte reference to the facts should not go beyond quotation from the records and papers on file in the Court; but even in extreme cases it is better to avoid any ex parte statement."

A strengthened canon of legal ethics, coupled with voluntary nondisclosure by law enforcement officials, comprise the solution to prejudicial publicity presented by the Special Committee on Radio, Television and the Administration of Justice of the Association of the Bar of the City of New York. See N.Y. Times, Feb. 24, 1967, p. 18, cols. $1-5$ (city ed.).

${ }^{233}$ See, e.g., Stanton, Free Press. v. Fair Trial: The Broadcaster's View, 41 N.D.L. REv. 7, 10 (1964); Wiggins, The Press and Conflicts of Interest, 24 FED. B.J. 358, 361-62 (1964).

${ }^{234}$ See Wright, supra note 193, at 438.

2se STANDARDS §1.3. But cf. Spevack v. Klein, 385 U.S. 511 (1967).

${ }^{230}$ See Shepard v. Maxwell, 384 U.S. 333, 361 (1966); State v. Van Duyne, 43 N.J. 369, 389, 204 A.2d 841, 852 (1964), cert. denied, 380 U.S. 987 (1965); Jaffee, Trial by Newspaper, 40 N.Y.U.L. REv. 504, 520-21 (1965); of. Lance v. Plummer, 353 F.2d 585 (5th Cir. 1965), cert. denicd, 384 U.S. 994 (1966). But cf. Spevack v. Klein, supra note 235. ${ }^{237} 360$ U.S. 622 (1959) (5-4 decision).

${ }^{285} \mathrm{Id}$. at 626-27.

${ }^{230}$ See Jaffee, Trial by Ncwspapcr, 40 N.Y.U. L. REv. 504, 520 (1965).

240 See Wood v. Georgia, 370 U.S. 375 (1962); Craig v. Harney, 331 U.S. 367 (1947); Pennekamp v. Florida, 328 U.S. 331 (1946); Bridges v. California, 314 U.S. 252 (1941). ${ }^{241}$ See Jaffee, Trial by Newspaper, 40 N.Y.U.X. REv. 504, 520 (1965).

24: The past history of constructive criminal contempt in the United States illustrates 
There is greater controversy concerning the restriction of the second class of persons designated by the Standards, namely, law enforcement officers. ${ }^{243}$ Many have been quick to challenge not only the wisdom but the legality of such restrictions, citing both the public's need to know that the police are functioning efficiently and the need for public scrutiny of police methods. ${ }^{244}$ It should be noted that under the Standards' proposal there would not be total suppression of police releases, but merely a delay until they could not influence the trial of the arrested person. ${ }^{245}$ Public pressure might not be able to immediately correct abuses if a delay were required, nor could there be instant announcement of the efficiency of law enforcement; however, the same overall results might still be achieved after the danger to an individual accused had passed. Much of the restricted material would be of public record, such

how the effectiveness of the contempt power can be expanded or circumscribed by judicial interpretation. The Judiciary Act of 1789 , ch. $20, \S 17,1$ Stat. 83, empowered the courts of the United States to "punish by fine or imprisonment, at [their] . . . dis. cretion ... all contempts of authority in any cause or hearing before [them] ...." In 1831, after several abuses of this unlimited power resulting in the procecdings of im. peachment against Federal District Judge James H. Peck, [see STANDSBURY, RePorT OF THE Trial of James H. Peck (1833)], Congress passed the Act of March 2, 1831, 4 Stat. 487 [substantially embodied in 18 U.S.C. $\$ 401$ (1) (1964)], which limited the power of summary punishment to "misbehavior" in the "presence of" the court, or "so near thereto as to obstruct the administration of justice." The Court sustained the act in Ex parte Robinson, 86 U.S. (19 Wall.) 505 (1873). With the passage of time the historical antecedent of this act became obscured and in Toledo Newspaper Co. v. United States, 247 U.S. 402 (1918), over dissents by Justices Brandeis and Holmes, the Court construed the "so near thereto" provision in causal rather than a geographical sense and sustained the use of constructive criminal contempt, thus reducing the act to its pre-1831 form. In Nye v. United States, 313 U.S. 33 (1941), the Court overruled Toledo and construed the words "so near thereto" in a geographical sense. See generally United States v. Rees, 193 F. Supp. 864 (D. Md. 1961).

${ }^{243}$ Standards $\$ 2.1$. See also id. $\$ 2.3$ (prohibiting disclosures by judicial employees).

The STANDARDS do not, however, confront the problem of disclosure by government officials, which can be as pernicious as the actions which the STANDARDs do restrict. See Delaney v. United States, 199 F.2d 107 (1st Cir. 1952) (congressional subcommittee in. vestigation); United States v. Florio, 13 F.R.D. 296 (S.D.N.X. 1952) (state crime commission investigation).

244 See Daniel, Fair Trial and Freedom of the Press, Case \& Com., Sept.-Oct. 1966, p. 3, at 4, 6; Wiggins, The Press and Conflicts of Intcrcst, 24 FED. B.J. 358, 360-61 (1964); Wright, Fair Trial-Free Press, 38 F.R.D. 435-36 (1965).

Critics of restrictions on disclosure by police state that freedom of the press must of necessity include the right to gather, to print, and to circulate information and that any restrictions upon the sources of information are an indirect attempt to unconstitutionally abridge the freedom of the press. See Special Comm. on Free Press AND Fair Trial of the american Newspaper Publishers Ass'n, Report: Free Press and fair Trial 1-6 (1967).

${ }^{245}$ Standards 77-79. See Sigourney, Fair Trial and Free Press-A Proposed Solution, 51 Mass. L.Q. 117, 120 (1966). 
as a prior criminal record, but the results of restrictions on police disclosure in test cities $^{246}$ and the reasoning in many judicial opinions and scholarly writings ${ }^{247}$ suggest that these restrictions alone would do much to correct current abuses. The Standards would authorize use of the contempt power when there had been police disclosure after arrest or formal initiation of criminal proceedings, but would leave to departmental regulation and control restrictions during earlier periods. ${ }^{248}$ It may be that internal control would provide sufficient flexibility to allow some disclosure in a particularly heinous crime to prevent public panic and that the trial level and appellate remedies could then be invoked to ensure fairness to the accused.

The controversy attains climactic proportions with regard to the Standards' proposals recommending use of the contempt power against "persons who disseminate information by means of public communication." 249 The preface to the contempt proposals is a weak disclaimer of the powers advocated therein. ${ }^{250}$ The contempt power would be used against anyone who, knowing that a jury trial was in progress or that jury selection had begun, disseminated matter from a closed hearing contrary to judicial order or disseminated an extrajudicial statement relating to the defendant or to the issues in the case which went beyond the public trial record, if the statement was reasonably calculated to affect the outcome of the trial and seriously threatened to have that effect. ${ }^{251}$ The wisdom of restrictions of the news media has been widely debated, ${ }^{252}$ and the constitu-

\footnotetext{
240 See Standards 25-47; id. app. A 163-64 (comparison of Newark papers revealed over ninety per cent drop in the reporting of prejudicial matter following the decision in State v. Van Duyne, 41 N.J. 369, 204 A.2d 841 (1964), cert. denied, 380 U.S. 987 (1965)).

${ }^{247}$ See, e.g., Sheppard v. Maxwell, 384 U.S. 333, 359, 361 (1966); State v. Van Duyne, supra note 246, at 389, 264 A.2d at 852; Goldfarb, Public Information, Criminal Trials and the Cause Celebre, 36 N.Y.U.L. REv. 810, $833-34$ (1961); Note, 54 KY. L.J. 141, 151 (1965).

${ }^{248}$ STANDARDS $\S \S 2.1,2$. However, several authorities have contended that pressure exerted upon the police by the press accounts in part for the prejudicial disclosures made by law enforcement officials. See BARNes \& TeEters, New Horizons in Criminology 192-98 (2d ed. 1951); Puttkommer, Administration of Crimanal Law 55 (1953); TAFT, CRIMINology 210 n.47 (rev. ed. 1950). Whether the law enforcement officials will be able to resist the pressure to "cooperate" with the press and to enforce sufficient restrictions is an open question.

210 STANDARDS $\$ 4.1$.

250 Ibid.

${ }^{251} I d . \$ \$ 4.1$ (a)- (b).

${ }^{252}$ See INBAU \& SOWLE, CASES ON CRIMINAL JUstice 1094-96 (1964); Goldfarb, supra
} 
tionality of such controls has endured extensive discussion with a similar lack of resolution. ${ }^{253}$ The Supreme Court cases severely limiting the power to punish contempt by publication ${ }^{254}$ are explained away in the Standards and by some commentators as arising without statutory authority and in nonjury proceedings, ${ }^{255}$ but their general tenor cannot be ignored. ${ }^{256}$ The contempt proposals of the Standards seem to be based on the premise that a sufficiently clear standard will survive review, the foundation on which several statutory remedies proposed by commentators also rest. ${ }^{257}$ However, by imposing restrictions on the press only during trial, the Standards must either assume the adequacy of enforced nondisclosure on other sources to limit or eliminate press dissemination prior to trial, or strike the balance between fairness and dissemination so as to avoid the problem. The difficulties of impaneling an impartial jury must necessarily persist even under the Standards if the press is able to print prior to trial inflammatory matter obtained from nonprohibited sources, such as the victim or witnesses.

\section{CONCLUSION}

In order to secure a "fair trial" the Standards place the major burden of nondisclosure on the legal profession and law enforcement officials. ${ }^{258}$ Some members of the press feel that the burden should

note 247, at 824-31; Jaffee, The Press and the Oppressed-Part I, 56 J. CRMM. L., C. \& P.S. 1, 8.11 (1965); Jaffee, Trial by Newspaper, 40 N.Y.U.L. REv. 504, 517-24 (1965); Stanton, Fair Press v. Fair Trial: The Broadcaster's View, 41 N.D.L. REv. 7, 9-10 (1964); Wiggins, The Press and Conflicts of Interest, 24 FED. B.J. 358, 360.62 (1964); Wright, supra note 244, at 439; Comment, 51 CoRNell L.Q. 306, 318-22 (1966); Note, 60 Colum. L. REv. 349, 372-75 (1960); Note, 54 KY. L.J. 141, 143-50 (1965); Comment, 57 Nw. U.L. REv. 217, 226-38 (1962).

${ }^{253}$ See Comment, 51 CORNell L.Q. 306, 321-22 (1966).

254 See Wood v. Georgia, 370 U.S. 375 (1962); Craig v. Harney, 331 U.S. 367 (1947); Pennekamp v. Florida, 328 U.S. 331 (1946); Bridges v. California, 314 U.S. 252 (1941). 258 See STANDARDS 153-55; e.g., Goldfarb, supra note 247, at 831; Wright, supra note 244, at 439 .

250 See Jaffee, Trial by Newspaper, 40 N.Y.U.L. REv. 504, 523 (1965); Will, Free Press vs. Fair Trial, 12 DEPaul L. REv. 197, 211 (1963).

${ }^{257}$ See Jaffee, The Press and the Oppressed-Part II, 56 J. Crim. L., C. \& P.S. 158, 165-66 (1965); Jaffee, Trial by Newspaper, 40 N.Y.U.L. REv. 504, 528 (1965); Note, 54 KY. L.J. 141, 151-53 (1965); Comment, 57 Nw. U.L. REv. 217, 250 (1962).

${ }^{288}$ STANDARDS $\$ 1.1$ (statements by lawyers); id. \$2.1 (statements by law enforcement officials). This approach is to be contrasted with the English system where the major burden of nondisclosure is placed upon the press. See generally Fox, THE History OF CONTEMPT OF COURT 5-43, 202-26 (1927); Gillmor, Free Press and Fair Trial in Eng. lish Law, 22 WASH. \& LEE L. REv. 17 (1965); Goldfarb, supra note 247, at 824-28; Note, 34 N.Y.U.L. REv. 1278, 1280.82 (1959); Note, 34 U. CiNc. L. REv. 503, 518.22 (1965). 
be entirely on the press voluntarily to suppress inflammatory material, ${ }^{259}$ and they refuse to accept the notion of externally imposed restraints. ${ }^{200}$ Whatever the desirability of any particular remedy may be, it would seem that the tide is turning toward compulsory nondisclosure in some form. ${ }^{261}$ Should this result without a prior exhaustion of the possibilities of liberalized trial and appellate remedies and self-restraint by both press and bar, a great disservice will have been done to society. The main fault must then be with the bar for failing to enforce its own canon and for violating its trusteeship over the legal system. While the threat of contempt action may stimulate press reform, ${ }^{262}$ it is suggested that trial, appellate, and professional ethical standards first be thoroughly tested before resorting to the use of contempt. By such a procedure the bar would be upholding its trust and would strengthen public confidence in the profession. Only if such a concerted effort fails should the bar unite in favor of compulsory restrictions on the press, for only then can the need for them be adequately ascertained.

R.J.M.

S.P.P.

\footnotetext{
25: See Daniel, supra note 244, at 6-9.

260 Id. at 6.

${ }_{202}$ "[W]e must remember that reversals are but palliatives; the cure lies in those remedial measures that will prevent the prejudice at its inception." Sheppard v. Maxwell, 384 U.S. 333, 363 (1966). See Wright, supra note 244, at 439.

${ }^{202}$ See ibid.
} 